\title{
Facing disruptive technologies: Aligning purchasing maturity to contingencies
}

\begin{abstract}
Purpose - This research explores how purchasing could respond to disruptive technologies, by examining the assumptions underlying purchasing strategic alignment and purchasing maturity through a contingency lens.
\end{abstract}

Design/methodology/approach - This study employs a systematic review across purchasing maturity and purchasing strategic alignment literature. This is supplemented with exploratory case studies to include practitioners' views.

Findings - This research demonstrates that neither purchasing maturity nor purchasing strategic alignment are suitable approaches to respond to disruptive technologies. Purchasing maturity does not allow purchasing managers to select relevant practices. It also shows no consideration of any contingencies, which practitioners highlight as important for the selection of practices. Purchasing strategic alignment includes the company strategy as a contingency, but does not provide any practices to choose from. It does not include any other contextual contingencies considered important by practitioners. The findings indicate that linking the two research streams may provide a more suitable approach to responding to disruptive technologies.

Research limitations/implications - This research demonstrates the requirement to develop a new approach to responding to disruptive technologies, by linking purchasing maturity and purchasing strategic alignment to contextual contingencies. This is a currently unexplored approach in academic literature, which refutes the generally accepted premise that higher maturity unilaterally supports a better positioning towards technological disruption. This research also highlights a requirement for practitioners to shift their approach to 'best practices'.

Originality/value - This is the first research to systematically review the relationships between purchasing maturity and purchasing strategic alignment. It adds to contingency theory by suggesting that purchasing maturity models can support the achievement of strategic alignment. Future research directions are suggested to explore these relationships.

Keywords Purchasing, technology, maturity model, alignment

Paper type Literature review 


\section{Introduction}

Purchasing is continuously challenged by disruptive technologies, such as the increasing requirement to use analytics to manage big data. Disruptive technologies are those that significantly impact customer expectations by accelerating the rate of change in an industry; they "disrupt an established trajectory of performance improvement, or redefine what performance [means]" (Christensen and Bowen, 1996). Whilst disruptive technologies challenge a firm's strategic management, they also impact their supply chain and operations (Paulraj and Chen, 2007).

As part of this, disruptive technologies are widely expected to change every aspect of purchasing, including the management of the supply base, supply risk or supplier relationships (Brown et al., 2015). This raises the question, how purchasing should react to these new developments, if it wants to maintain or increase its positive impact on firm performance. Does this require radically new approaches or can established purchasing methods be adapted? In the purchasing literature, two research streams have evolved that provide approaches for purchasing to face disruptive technologies, which will be reviewed in this research.

First, purchasing maturity models measure the sophistication of the purchasing function, by classifying several purchasing practices into different maturity stages (Rozemeijer et al., 2003). They reflect purchasing's historic evolution and provide a tool to improve organisational purchasing, based on the assumption "that greater maturity is associated with better performance" (Schiele, 2007, p. 274). When faced with increasing technological disruption in the market place, a purchasing maturity approach would suggest increasing purchasing's level of sophistication across the practices included in the maturity model. For instance, maturity models frequently include the centralisation of the purchasing function, based on which a company might decide to centralise their purchasing in order to increase their ability to react to changes more quickly and uniformly.

In contrast, purchasing strategic alignment is derived out of general alignment theories on customer and shareholder alignment (Wong et al., 2012) and refers to the consistency of purchasing's strategy and activities with the firm's objectives (Baier et al., 2008). This theory would require purchasing to develop strategies for technological disruption together, and in alignment with, the firm's strategy. In contrast to purchasing maturity, purchasing strategic alignment would therefore make the selection of purchasing practices dependant on the company strategy. For instance, if the company strategy was to focus on local customer service, the company might shift more responsibility to the local purchasing team in order to allow the inclusion of individual customer requirements (e.g. David et al., 2002).

Through a contingency lens, this research aims to review the suitability of purchasing strategic alignment and purchasing maturity models in responding to disruptive technologies. Contingency theory posits that performance depends on the fit of a firm's strategy, structure and processes (Miles and Snow, 1984). Contingency theory relies on three core elements: Firstly, it assumes a relationship between organisational characteristics, the proposed contingency and firm performance. Secondly, changes in this contingency factor will, over time, cause changes 
in the organisational characteristic. Finally, contingency theory postulates that the fit between the contingency and organisational characteristics affects firm performance (Donaldson, 2001). This research therefore assumes that a firm's effectiveness in responding to disruptive technologies is dependent on the fit of the organisational set-up or approaches chosen with contingencies.

This research will thus focus on the research question: How can purchasing maturity and strategic alignment support purchasing's response to disruptive technologies? This question aims to better understand purchasing maturity and purchasing strategic alignment as the two approaches outlined by academia and their suitability in an environment characterised by technological disruption. It is supported by three sub-questions, which will guide the analysis:

- What are purchasing strategic alignment and purchasing maturity and how do they propose to respond to disruptive technologies?

- How do purchasing strategic alignment and purchasing maturity relate to disruptive technologies?

- How do practitioners select purchasing strategies and practices in response to technological disruption?

This research makes a novel contribution to literature by demonstrating that neither purchasing maturity nor purchasing strategic alignment on its own are suitable approaches to respond to disruptive technologies, but indicates that it may be beneficial to relate the two concepts going forward. The case studies highlight that any future approach also needs to consider contextual contingencies.

The remainder of the paper describes the methodology used for the systematic literature review and the exploratory cases. These will be analysed in the findings section, starting with separate discussions of the two approaches and followed by a comparison to practitioner perceptions. Finally, the results are discussed in the context of contingency theory and the implications for theory and practice are considered.

\section{Methodology}

This research is primarily based on a systematic review of academic literature, supplemented by exploratory case studies. These elements will be described in more detail in the remainder of this section.

\subsection{The systematic literature review}

Academic research was reviewed to understand purchasing maturity and purchasing strategic alignment as two potential approaches to respond to disruptive technologies. Systematic reviews aim to reach reasonable conclusions about the body of knowledge using a rigorous methodology to identify, select and analyse existing research. This research followed Tranfield et al. 's (2003) process, which will be reported in this section, including the review question formulation, research identification, selection and quality assessment that resulted in the final set of papers taken forward into the analysis. 
Question formulation. Review questions define the questions to be put to the literature, in contrast to the research questions, which guide the analysis and discussion. The review questions for this study were refined with a panel of experts on different topics, including literature reviews, purchasing, strategic alignment, and qualitative and quantitative methods. The final review questions addressed by this study are:

rv1: How are purchasing strategic alignment and purchasing maturity conceptualised and measured in academic literature?

rv2: How do purchasing maturity models relate to purchasing strategic alignment?

Research identification. Based on these questions, two search strings were developed focusing on purchasing maturity and purchasing strategic alignment. Strategic purchasing was included as an additional keyword, as the concept often includes aspects of strategic alignment. The resulting two search strings were applied to the title and abstract searches of peer-reviewed journals in ABI/Inform Complete (ProQuest) and EBSCO in July 2017. The search was limited to scholarly, peer reviewed articles with no time limitations. The final two search strings for ABI/Inform Complete (ProQuest) are described below ("NEAR3" was replaced with "N3" for EBSCO):

1. (purchas* OR procur* OR "supply management" OR "supply-management" OR buy*) NEAR/3 (maturity OR “development model” OR stages OR levels OR "best practices" OR configuration)

2. ((purchas* OR procur* OR "supply management" OR "supply-management" OR buy*) NEAR/3 (align* OR misalign* OR integrat* OR fit*)) OR ("strategic purchasing" OR "strategic sourcing" OR "strategic procurement")

This review initially included systematic searches for conference papers to include the most recent research, and consultancy studies to include a practitioner perspective. However, these studies were excluded as they were limited both in number (no conference papers and eight consultancy studies) and evidence, as the consultancy studies did not significantly add to the findings.

Research selection. The identified papers were screened for relevance to the research question, focusing on the context of the study, the topical fit, the publication type and the language (Table 1). These criteria were applied in two stages, initially subjecting the resulting papers to a title and abstract screening, followed by a full text screening.

\section{--- Insert Table 1 around here ---}

Table 2 provides an overview of the papers taken forward at each step. Of the 4,203 papers identified initially, 378 papers satisfied the selection criteria based on their title and abstract, which were reduced to 240 papers by removing duplicates. These were further reviewed based on their full text, resulting in 87 papers. Common reasons for excluding papers at this stage were the context (e.g. e-procurement papers focusing on IT instead of purchasing), topical fit 
(e.g. focus on integration instead of alignment) or the methodological rigour (e.g. lack of description of methods used). These criteria were consistent with the initial selection criteria, which could however not be identified from the title and abstract screening. An additional 17 papers satisfying the selection criteria were identified through reference searches, resulting in 104 papers used in the analysis.

\section{--- Insert Table 2 around here ---}

Quality assessment. Although quality was assessed, no papers were excluded due to quality criteria. The research focuses on underlying assumptions that can be informed by all papers, independent of their quality, as they are read by other academics and therefore constitute the body of knowledge. However, quality criteria will be discussed in the relevant sections.

Data extraction. The data extraction included general paper information, data on the methodology chosen and details on maturity models, strategic purchasing and strategic alignment.

\subsection{Exploratory cases}

Exploratory cases were included to understand applied purchasing in a business context. They were selected in an attempt to include polar types, to support the exploratory nature of this research (Eisenhardt, 1989; Pettigrew, 1988). Firm size and industry were chosen as the main characteristics expected to impact findings, based on Pressey et al.'s (2002) claim that SMEs may benefit more from effective purchasing than larger enterprises and Ellram et al.'s (2002) conclusion that 'best practices' may differ across industries.

The final cases included two food manufacturers, one bank and one automotive aftermarket firm. The firms were diverse in terms of size (revenue and employees) and industry. For confidentiality reasons, these firms are referred to as BANK, FOOD, CAR and DRINK. Detailed characteristics for each case study are provided in Table 3.

\section{--- Insert Table 3 around here ---}

Data collection. Data was collected primarily through one-hour face-to-face interviews with the Head of Purchasing (or an equivalent title). The interviews followed a semi-structured interview protocol, which was reviewed by a panel of experts prior to the interviews. The topics covered interviewees' perceptions of purchasing strategic alignment and the application of purchasing practices. All interviews were recorded with prior permission and were fully transcribed and sent to the interviewees for validation.

Data analysis. Interviews were analysed with NVivo, using template analysis, which aggregates textual data into a hierarchy of themes. This method has been chosen for its flexibility in approaching the analysis and in coding levels (King, 2012). As the objective was to understand 
practitioners' views and perceptions, no a priori themes were defined. Instead, the analysis focused on emerging themes, which were aggregated into higher level codes. The development of the final template was based on iterations between emerging themes and transcripts. A sample of the coding structure is provided in Table 4. It highlights the coding structure for two key elements used in the analysis (contingencies for purchasing strategic alignment and purchasing maturity). A similar approach was used for other topics, such as the purchasing strategy elements or the purchasing practices mentioned.

\section{--- Insert Table 4 around here ---}

The interviews were triangulated with secondary and publicly available data, to define the industry background and firm strategy. This was generally based on firm websites but supported by online search engine results and business information websites.

Study rigour. Case study research is commonly judged based on construct validity, internal validity, external validity and reliability (Yin, 1994, p. 33). Construct validity was ensured through triangulating interview data with publicly available information and by relying on those interviewees that were expected to have the best visibility of the purchasing process. Although internal validity was limited by the single interview approach, these cases were exploratory in character and benefited from the four different contexts. The small sample and diverse case selection will limit external validity, which was accepted in favour of more variety to support the exploratory nature of this research. Reliability was ensured through transparency in data collection and analysis.

\section{Findings}

The findings will start with a descriptive analysis of the academic literature, followed by a comparative analysis of academic papers and a detailed analysis of purchasing maturity and purchasing strategic alignment literature, supplemented by case study findings.

\subsection{Descriptive analysis: Academic papers}

Whilst the main analysis will consider strategic purchasing as a part of strategic alignment literature, this section will distinguish between 'pure' strategic alignment literature and strategic purchasing literature to highlight the differences in assumptions.

The majority of papers reviewed focus on strategic purchasing (59 papers), compared to 35 papers focusing on purchasing maturity and only 18 based on 'pure' conceptualisations of strategic alignment. Apart from three early contributions, all three topics only picked up in the late 1980s, with an increasing number of contributions since 2000 (Figure 1). 
Methodologically, early papers were frequently conceptual. However, survey research has become predominant since the late 1990s, supported by case studies. This reliance on deductive research (surveys and conceptual papers make up $70 \%$ of papers) indicates a predominance of positivist epistemologies, especially since case studies are often used to test a maturity model, not to explore underlying assumptions. For a relatively unexplored field, there appears to be little inductive research to understand practitioners' views.

$67 \%$ of papers reviewed also do not clearly state a theoretical perspective to explain their findings. Where a theory is used, it is frequently the resource-based view or its extension, the relational view, arguing that purchasing is a strategic capability that can drive competitive advantage through strategic resources (Carr and Pearson, 2002). Strategic alignment papers also use contingency theory, proposing that competitive advantage stems from the fit of purchasing's activities and objectives with the firm strategy (Baier et al., 2008). Contingency theory is never used by maturity or strategic purchasing research.

\subsection{Comparative analysis of academic papers}

For the purpose of this section, academic papers were classified by their main topic and the type of key finding, as demonstrated in Table 5. The findings move from conceptual and exploratory research, such as the development and testing of frameworks and concepts, to more mature testing of hypotheses, including the analysis of the relationship with performance.

\section{--- Insert Table 5 around here --- \\ --- Insert Table 6 around here ---}

The different types of findings demonstrated in Table 6 align with the cycle of theory construction and testing (Wallace, 1971, quoted in Blaikie, 2007, p. 81), in which the development and testing of frameworks and concepts would align with more inductive research for theory generation, and the testing of relationships aligns with the more deductive theory testing. It could therefore be expected that earlier research is more exploratory in nature, possibly focussing on case studies or conceptual work, whilst later work could be expected to focus on more deductive methods, such as surveys.

To test this alignment between theory generation or testing with different methods, Table 6 summarises the theory and method as well as key strength and weaknesses for each of these findings per theme.

Purchasing strategic alignment, as a young field of research, focuses on the development and testing of frameworks. It shows a strong theoretical basing and whilst different authors use different approaches, these lead to corroborative findings that generally show that companies should focus on different purchasing practices depending on their strategic orientation. For instance, very early conceptual papers (e.g. Farmer, 1981; Watts et al., 1992; Spekman, 1989) argue for more alignment of purchasing objectives with the company strategy. Their research is 
later formalised, for example by Gonzáles-Benito (2007) and Baier et al. (2008), who use the theory of production competence to develop a framework for purchasing alignment and link this to performance. Other authors try to identify under which circumstances certain purchasing practices are more suitable, like Narasimhan and Carter (1998), who find that companies use different sourcing strategies depending on their competitive priorities, or David et al. (2002), who find that companies that align their purchasing organisation to their competitive strategy achieve better performance. However, there is limited empirical testing of these theories, especially of the more exploratory and inductive research, as conducted by Narasimhan and Carter (1998). Therefore, the findings in this field remain somewhat generic and, with some exceptions, do not define under which circumstances which practices are more suitable.

Within strategic purchasing literature, there is some conceptual work focusing on the development of frameworks, but most papers focus on testing how strategic purchasing relates to other purchasing capabilities and performance. It could be argued that this testing of relationships is done somewhat prematurely, especially considering that some of the papers reviewing the strategic purchasing concept challenge existing concepts (e.g. Ramsay and Croom, 2008) and the limited theoretical grounding of strategic purchasing literature. Moreover, conceptualisations differ significantly between papers. For instance, in Ellram and Carr's (1994) definition strategic purchasing is about a more recognised purchasing function that acts more strategically in alignment with the overall company strategy. However, later papers also include concepts like supplier partnerships (e.g. Cousins et al., 2006) or supplier selection and evaluation (e.g. Luzzini et al., 2014). These differences in conceptualisations question to what extent the identified relationships are generalizable or if there are underlying concepts and relationships that are yet unidentified.

Table 6 initially appears to indicate a strong conceptual basing for purchasing maturity. However, the more conceptual papers in this field tend to develop and test a maturity model, generally not reviewing underlying concepts or assumptions. There is also limited to no theoretical basing. Instead, purchasing maturity literature appears to be strongly linked to and based on strategic purchasing research (e.g. Cousins et al., 2006, Paulraj et al., 2006). Moreover, most papers do not critically review previous work, assimilating the assumption that purchasing maturity is generally linked to better performance. For instance, Bemelmans et al. (2013) state in their abstract that "the more developed (i.e. mature or professional) this function is, the greater its positive contribution" to then continue and develop a purchasing maturity model which "provides a company with insight into its current level of purchasing maturity and possibilities for improving performance by increasing this level". This assumption of a link between higher maturity and performance remains predominant in purchasing maturity literature, in spite of contradictory literature. For instance, after failing to find a relationship between maturity and performance Ellram et al. (2002) discuss that this may be due to the fact that they adopt this assumption, when the suitability of purchasing practices may differ across industries and firms. Like strategic purchasing, purchasing maturity research is further limited by the differences in concepts and measurements. 


\subsection{Purchasing maturity}

The following section summarises academic and practitioner conceptualisations of maturity. The elements will first be analysed individually, followed by a comparison of findings.

\subsubsection{Academic conceptualisation of purchasing maturity}

This section will analyse different interpretations of maturity in four key areas: the topics included in maturity models, the maturity measurement, the unit of analysis, and the consideration of strategic alignment.

Most maturity models are developed deductively based on existing literature, yet they cover vastly different topics, indicating a level of disagreement on what constitutes maturity. Some topics are covered frequently, especially strategic planning, supplier selection criteria, purchasing's involvement in organisational activities, strategic supplier relationships, and controlling and performance measurement.

Different measurements are used for purchasing maturity (Figure 2). Whilst the majority of papers are based on aggregate measures, some papers also measure a maturity profile, where each aspect of the maturity model is scored individually. An aggregate maturity measure assumes that the purchasing function can only develop as a whole, whereas a profile allows different aspects of purchasing to develop at different rates. Where Paulraj et al. (2006) identified three aggregate levels or taxonomies of purchasing maturity, Bemelmans et al. (2013) assessed maturity in different topics (here referred to as 'maturity profiles') and compared these to a past assessment to provide a detailed analysis of improvements achieved.

\section{--- Insert Figure 2 around here ---}

Maturity is also measured at different corporate levels, indicating different units of analysis. $80 \%$ of papers measure maturity at the firm or business unit level, with only a few papers using the category or individual buyer level. For instance, Schiele (2007) addressed the firm level to assess maturity, while Beukers et al. (2006) compared the maturity profiles between two categories of a financial services company and Deasy et al. (2014) compared two departments in an emergency service. Both found that different categories have different maturity profiles.

Finally, Figure 2 demonstrates that most papers (66\%) do not consider alignment in their maturity models. If alignment is considered, it is conceptualised in two different ways:

1. As maturity congruence, either between different maturity aspects (e.g. Mikalef et al., 2015) or between purchasing and the firm (e.g. Cavinato, 1999). As argued for strategic alignment, this refers to a concept that is different from purchasing strategic alignment

2. Consistent with the definition used in this paper and referred to as purchasing strategic alignment 
If conceptualised as strategic alignment, it is usually measured as a topic or as a stage in the maturity model, assessed by the respondents or researchers. Measures are similar to strategic alignment (Paulraj et al., 2006).

Underlying these different conceptualisations of maturity is the generally accepted assumption that purchasing needs to achieve a generic higher stage of maturity to achieve better performance, or as a response to disruptive technologies. For example, several maturity papers include a more centralised purchasing structure as one of the maturity aspects. This assumption is in direct contrast to findings from purchasing strategic alignment research: David et al. 's (2002) finding that the level of centralisation is contingent upon the firm strategy.

\subsubsection{Case study findings: Perceptions of purchasing practices}

This section will focus on practitioners' perceptions of purchasing maturity. Most interviewees identified some practices they feel would apply to any purchasing organisation, such as segmentation, systems or centralisation. Similarly, some purchasing practices were mentioned across cases, including category management, centralisation and supplier relationship management (BANK, CAR, FOOD, DRINK).

However, the interview analysis also suggested that other practices may be more distinct to different cases. For example, BANK was the only one to mention contract renegotiation, while CAR mentioned requests for more sales involvement. FOOD uniquely mentioned responsible sourcing and DRINK explained their involvement in New Product Development.

None of the managers referred directly to the purchasing or category strategy as a basis for purchasing practice selection. Instead, they grounded their selection in different contextual contingencies very similar to the contingencies identified for purchasing or category strategies, albeit in contrast to purchasing strategies, technological contingencies were not mentioned for purchasing practices. These contingencies are summarised in Table 7.

\section{--- Insert Table 7 about here --}

\subsubsection{Summary: Conceptualisations of purchasing maturity}

The review of academic literature indicates that the term 'purchasing maturity' has been interpreted differently, indicating a level of fragmentation within the field. Conceptualisations of maturity differ in terms of the topics considered, the unit of analysis as well as the measurement type (aggregate or profile). Maturity models generally do not appear to consider strategic alignment but instead rely on the assumption that purchasing needs to achieve a generic higher maturity level.

This differs from the findings from case studies, which indicate that whilst some aspects of purchasing maturity may be universally applicable, other elements are driven by their unique context and not applied across different firms. 


\subsection{Purchasing strategic alignment}

This section will review how purchasing strategic alignment is conceptualised, starting with an independent analysis of academic research and practitioner perceptions, followed by a comparison of the two.

\subsubsection{Academic conceptualisation of purchasing strategic alignment}

The identified literature on purchasing strategic alignment can be distinguished into three different conceptualisations:

1. Strategic alignment: Only 26 papers (25\%) follow the definition used in this research as the consistency of purchasing strategies and activities with corporate objectives. These will be discussed in more detail below

2. Strategic purchasing papers use a multi-measure construct covering different aspects (37 papers - 36\%). In agreement with Carr and Smeltzer's (1997) definition, early papers focus on alignment and strategic planning measures. However, later research includes a broad number of aspects, including supplier relationship management, supplier selection or professionalism. These aspects measure different concepts with different relationships to technological disruption

3. Congruence focuses on the alignment of levels of maturity across different categories or between purchasing and the firm (4 papers $-4 \%$ )

Both strategic purchasing and congruence provide an important background, but are different concepts from purchasing strategic alignment.

The remaining papers using 'pure' strategic alignment conceptualisations rely on different measurements. Seven out of the 26 papers do not define any measure for alignment, usually the conceptual papers without empirical data. Another 13 papers measure strategic alignment either directly on a Likert scale or as part of a maturity matrix. Both rely on respondents' perceptions to determine the extent of strategic alignment, using measures such as:

- Purchasing performance is measured in terms of its contributions to the firm's strategic objectives

- Purchasing plans are continuously revised to adapt them to changes in business strategic planning

- The purchasing function has a good knowledge of the firm's strategic goals (e.g. Handfield et al., 2015; Kaufmann and Gaeckler, 2015)

The remaining papers measure strategic alignment indirectly by predefining purchasing aspects that may require alignment with the corporate strategy. They then continue to measure respondents' answers regarding the fit with the hypothesised relationships. Table 8 demonstrates how the alignment construct is defined, which business strategies and purchasing aspects are considered, as well as the measurement basis for fit. It highlights a lack of agreement on what business or purchasing strategies exist, which purchasing strategies align with which business strategies, as well as the measurement basis for fit. 


\section{--- Insert Table 8 about here ---}

\subsubsection{Case study findings: Perceptions of purchasing strategy and strategic alignment}

This section presents a review of the findings from the exploratory case studies, which will be compared to the academic literature in the following section.

The term 'purchasing strategy' does not appear to be clearly defined in industry, as demonstrated by interviewees enquiring what was meant by the term and the different explanations provided, ranging from current change programmes to defined purchasing practices (BANK, FOOD). These differences in perceptions could be explained by the implication of a functional strategy, which was contradicted by FOOD and DRINK, who stressed that strategies are different for each category, supported by a definition of structures and principles at a functional level.

Purchasing professionals also demonstrated different reactions to the concept of purchasing strategic alignment. Similar to academic conceptualisations, BANK expressed that purchasing strategy should be based on the firm strategy. However, other interviewees did not perceive a direct link between purchasing and firm strategy.

Instead, interviewees referred to some important contingencies that determine the purchasing or category strategy. These can be classified into four categories: internal contingencies, external contingencies, technological contingencies and product and supply driven contingencies (Table 9). Whilst product and supply driven contingencies include internal and external contingencies, these are distinguished from internal and external contingencies, as they can be more easily influenced through sourcing and range decisions. It is also noteworthy that whilst strategic alignment was analysed as a response to disruptive technologies, systems vulnerability and technology trends were also included as contingencies to purchasing strategies.

\section{--- Insert Table 9 about here ---}

Despite the initial appearance of an absence of strategic alignment, the perceived purchasing strategy contingencies hint at an alternative explanation. All described contingencies are likely to be common to the whole firm (rather than just the purchasing function). This indicates a tacit concept of strategic alignment, driven by a common understanding of the firm's environment and challenges, rather than a procedural analysis of corporate priorities.

\subsubsection{Summary: Conceptualisations of purchasing strategic alignment}

The analysis demonstrates that purchasing strategic alignment is not clearly defined in academia or practice. Academic literature includes aggregate constructs, such as strategic purchasing or congruence conceptualisations next to strategic alignment, which hinders the understanding of underlying relationships. The case studies indicate that purchasing professionals ensure strategic 
alignment is on a more tacit and implicit basis, driven by the business context and an understanding of the firm's challenges.

Strategic alignment research commonly distinguishes business strategies into cost leadership and differentiation (Baier et al., 2008; David et al., 2002; Rozemeijer et al., 2003), which is contradicted by Narasimhan and Carter's (1998) research into relevant business strategies, indicating that some further research is necessary to define the relationship between purchasing strategies and firm strategies.

\section{Discussion}

This study reviewed how two approaches raised in purchasing literature, purchasing strategic alignment and purchasing maturity, could be used to respond to disruptive technologies. The analysis highlights shortcomings with both approaches, which will be discussed in the context of contingency in the following section.

\subsection{Purchasing maturity: A collection of 'best practices'}

First, purchasing maturity proposes to increase purchasing's sophistication by applying purchasing best practices to increase purchasing's ability to respond to changes in the environment (Rozemeijer et al., 2003). Whilst this approach is supported by a large amount of empirical research, not all papers come to the conclusion that generic higher maturity is related to better performance (e.g. Ellram et al., 2002). Moreover, the field is highly fragmented in terms of what practices should be improved (the content of maturity models), at what level these should be improved (the unit of analysis) and how maturity should be measured (profile or aggregate). These differences raise questions about the generalisability of findings and whether there are underlying constructs that determine the suitability of purchasing maturity as an approach to respond to disruptive technologies.

There is also limited to no theoretical basing used in purchasing maturity research. From a contingency perspective, the level of maturity and the practices chosen would be dependent on a contingent element (Donaldson, 2001). This is generally not considered in the reviewed literature, with some noteworthy exceptions: Ellram et al. (2002) conclude that it may be more important to select the practices that fit with the context of a firm than to increase purchasing maturity overall. Indeed, Beukers et al.'s (2006) and Deasy et al.'s (2014) research demonstrated differences in the maturity profiles of different categories, which they attribute to the different category characteristics. These findings can be explained by contingency theory, indicating that the practices included in a maturity model, and the levels to which maturity is desirable in each of these practices, is contingent upon contextual factors, such as product or market characteristics - for instance, a firm with more suppliers may need a more sophisticated approach to data and supply market analytics, where a firm dealing with only few suppliers may not require as sophisticated technological skills in this area.

This is supported by findings from case studies, which highlight a differing interpretation of purchasing maturity. Whilst some practices may be common to all firms, practitioners generally choose purchasing practices depending on specific contextual contingencies. These 
contingencies are very similar to the contingencies mentioned for purchasing strategies, indicating that it may be beneficial to link purchasing strategic alignment and purchasing maturity research going forward. Contextual contingencies could thus be used to select the required maturity profile for purchasing to face technological disruption - enabling firms to invest in the most important practices.

In summary, purchasing maturity models provide a range of best practices, but no practical or theoretical explanation as to why or under which circumstances these are important.

\subsection{Purchasing strategic alignment: An approach to choose most suitable practices}

Purchasing strategic alignment proposes that a suitable approach to face disruptive technologies would be aligning purchasing practices to the firm's strategy. Purchasing strategic alignment is a relatively undeveloped research field, however, with a strong theoretical and conceptual basis. This research demonstrates that purchasing strategic alignment research aligns with the three premises of contingency theory (Donaldson, 2001). First, it assumes an underlying relationship between purchasing characteristics and contingencies, as demonstrated by the relationship between purchasing and firm strategy. Second, it clearly states the importance of regularly reviewing the purchasing strategy to adapt to changes in the firm strategy. Finally, academic research supports the positive effect of fit between contingencies and purchasing characteristics on firm performance (Baier et al., 2008; Gonzáles-Benito, 2007), thus providing a valuable approach to face disruptive technologies.

However, purchasing strategic alignment is conceptualised differently, often as strategic purchasing, which usually includes principles of strategic alignment, but also measures such as status, planning or supplier relationships, which do not align with contingency theory premises. Strategic purchasing research is very comparable to maturity research and indeed the analysis demonstrates that these two research streams often overlay. But even 'pure' conceptualisations of alignment differ in the strategies considered, in the purchasing aspects aligned and in the measurement of fit.

Moreover, academic literature generally assumes a procedural concept of strategic alignment, in which the purchasing strategy follows the firm strategy as a single contingency (e.g. Watts et al., 1992). In contrast, practitioners described their strategies as being based on several contingencies, including internal, external, technological and product- or supply-based factors. Moreover, these contingencies were often expressed as problems faced, thus indicating a more tacit (rather than procedural) concept of alignment.

In conclusion, purchasing strategic alignment provides an approach to select the most suitable practices for responding to disruptive technologies, but it does not provide any practices to choose from and it is limited in its considerations of contingencies. Purchasing strategic alignment only considers the company strategy, which is an important, but by far not the only contingency practitioners mentioned. Indeed, practitioners considered disruptive technologies as a contextual contingency, which is interrelated with other contextual contingencies defined by practitioners, such as the company culture or product characteristics. 


\subsection{Aligning purchasing maturity: A suitable response to disruptive technologies?}

Purchasing maturity and purchasing strategic alignment are generally not linked in academic literature. If they consider alignment at all, maturity models include strategic alignment as one aspect to be assessed as part of the maturity model (e.g. Paulraj et al., 2006; Bemelmans et al., 2013). In contrast, strategic alignment includes no notion of maturity or a pre-defined set of purchasing practices to be aligned, thus remaining rather generic without clear directions for practitioners.

Indeed, the two research streams currently appear to contradict each other. For example, David et al. 's (2002) finding that purchasing centralisation is contingent upon firm strategy challenges maturity models that assume a general requirement for higher centralisation.

From a contingency perspective, strategic alignment should be included in purchasing maturity models, in that the desirable maturity level for each of the practices is contingent upon the purchasing strategy, thus ensuring a consistent approach to facing technological disruption (Donaldson, 2001). This would enable purchasing maturity models to move beyond the assumption of a generic link between 'best practices' and performance. Instead, they could provide an approach of identifying the most suitable practices and ensure that purchasing practices and capabilities are aligned to the firm's context and objectives when facing technological disruption, as suggested by Chen et al.:

"it is the unique combination of [purchasing and supply management] practices or activities and their configuration with the firm's strategic goals as well as other firm-specific resources and capabilities that may inhibit imitation of the firm's competitive advantage" (Chen et al., 2004)

However, practitioner interviews highlight that purchasing strategic alignment needs to be extended beyond the alignment with the company strategy, to include other contingencies, such as disruptive technologies or product characteristics.

This research indicates that integrating purchasing maturity and strategic alignment research, by using strategic alignment to determine the required level of maturity may provide firms with an approach to determine this unique combination of purchasing and practices necessary to responding to disruptive technologies.

\section{Conclusion and Limitations}

Academic literature currently provides two distinct approaches purchasing managers can follow when facing technological disruption: Increasing their purchasing maturity or increasing their alignment with the firm strategy. Using a contingency lens, this research extends current literature on purchasing maturity and purchasing strategic alignment to identify a more appropriate approach: Using purchasing maturity models to select the most suitable practices and capabilities to respond to technological disruptions, based on, and in alignment with, contextual contingencies.

This research thus contradicts purchasing maturity research in their assumption that higher maturity is generally related to better performance. Instead, strategic alignment research and the exploratory cases indicate that the selection of practices (maturity topics) is dependent on 
contextual contingencies, including the company strategy and the technological disruption in the industry. These findings are in alignment with contingency theory principles, especially the dependency of company characteristics on contingent factors.

This research contributes to academic literature by providing a novel approach to responding to disruptive technologies, which uses core elements from both purchasing maturity and purchasing strategic alignment research, as well as a wider range of contextual contingencies. It suggests that the consideration of contingencies when assessing a firm's maturity could transform purchasing maturity models from a collection of 'best practices' into an instrument that supports the achievement, and measurement of, purchasing strategic alignment.

For practitioners, these findings imply that the technological disruptions of the $21^{\text {st }}$ century may not require searching for and applying 'best practices' generically. The more effective approach would be a thorough analysis of the purchasing context, to identify those maturity topics that will have the most impact on firm performance. This would focus improvements on the most beneficial areas and ensure the best possible return on investment. For instance, a food manufacturer facing high public interest in ethical sourcing may well focus on using disruptive technologies to trace origins for ingredients through a multi-tier supply chain. In contrast, a packaging manufacturer focusing on cost reductions, may instead use disruptive technologies to inform competitive tenders through better supply market analysis.

By critically reviewing existing literature on purchasing strategic alignment and purchasing this research has highlighted significant gaps in both fields. First, the comparative analysis has highlighted a lacking theoretical and conceptual basing for purchasing maturity research as well as a requirement to further test purchasing strategic alignment research. Moreover, the findings appear somewhat paradoxical in that the research initially assumed purchasing strategic alignment and purchasing maturity to be approaches to respond to disruptive technologies. However, the analysis indicated that technological disruption may also be a contingency to purchasing strategies as well as a purchasing practice included in maturity models.

Future research should therefore focus on providing further clarity on the concepts reviewed, including determining a theoretical grounding and clarifying concepts for purchasing maturity (i.e. what content should be considered? Do any contingencies need to be considered? Etc.) However, this research has also shown the requirement to further investigate this field, covering questions such as:

- How generalisable is purchasing maturity? And is this dependent on another factor, such as the level of technological disruption, the measurement level (category vs function), the 'best practices' included or the industry?

- What are the contingent factors that drive procurement strategies and practices?

- How suitable is linking strategic alignment and purchasing maturity as a new approach to responding to disruptive technologies? And is this indeed an approach unique to a disruptive environment, or is this a suitable approach irrespective of the level of disruption? 
- Is technological disruption a contingency to strategic alignment and maturity or an environment firm act in - or both?

Some research limitations must be noted. The small number of case studies limits the external validity and thus the inferences that can be made. Future research could address this limitation through larger studies, possibly using survey research or archival data. Whilst demonstrating different interpretations from academic conceptualisations of alignment, the detailed relationships between purchasing and context require further research. This gap could be addressed by explicitly linking and even merging strategic alignment and purchasing maturity research.

This research provides a review of purchasing strategic alignment and purchasing maturity literature as two approaches that could be used in the facing of increasing technological disruption. It defines a theoretical basing and raises important questions to be addressed, thus supporting future research on purchasing strategic alignment and purchasing maturity.

\section{References}

Adams, J., Kauffman, R.G., Khoja, F.M. and Coy, S. (2016), "Looking at Purchasing Development through the Lens of Small Business", Journal of Managerial Issues, Vol. 28 No. 3/4, pp. 145-170.

Adamson, J. (1980), “Corporate Long-range Planning Must Include Procurement", Journal of Purchasing \& Materials Management, Vol. 16 No. 1, pp. 25-32.

Baier, C., Hartmann, E. and Moser, R. (2008), "Strategic Alignment and Purchasing Efficacy: An Exploratory Analysis of Their Impact on Financial Performance", Journal of Supply Chain Management, Vol. 44 No. 4, pp. 36-52.

Barney, J., 1991. Firm resources and sustained competitive advantage. Journal of Management 17 (1), pp. 99-120.

Barry, J., Cavinato, J.L., Green, A. and Young, R.R. (1996), "A Development Model for Effective MRO Procurement", International Journal of Purchasing \& Materials Management, Vol. 32 No. 3, pp. 35-44.

Bemelmans, J., Voordijk, H. and Vos, B. (2013), "Designing a Tool for an Effective Assessment of Purchasing Maturity in Construction”, Benchmarking, Vol. 20 No. 3, pp. 342-361.

Bemelmans, J., Voordijk, H., Vos, B. and Buter, J. (2012), "Assessing Buyer-Supplier Relationship Management: Multiple Case-Study in the Dutch Construction Industry", Journal of Construction Engineering \& Management, Vol. 138 No. 1, pp. 163-176.

Bernardes, E.S. and Zsidisin, G.A. (2008), “An Examination of Strategic Supply Management Benefits and Performance Implications", Journal of Purchasing \& Supply Management, Vol. 14 No. 4, pp. 209-219. 
Beukers, M., Versendaal, J., Batenburg, R. and Brinkkemper, S. (2006), "The Procurement Alignment Framework Construction and Application", Wirtschaftsinformatik, Vol. 48 No. 5 , pp. 323-330.

Blaikie, N. (2007), Approaches to Social Enquiry: Advancing Knowledge, Polity.

Bowen, F.E., Cousins, P.D., Lamming, R.C. and Farukt, A.C. (2001), "The Role of Supply Management Capabilities in Green Supply", Production \& Operations Management, Vol. 10 No. 2, pp. 174-189.

Bozarth, C., Handfield, R. and Das, A. (1998), "Stages of Global Sourcing Strategy Evolution: An Exploratory Study", Journal of Operations Management, Vol. 16 No. 2/3, pp. 241-255.

Brookshaw, T. and Terziovski, M. (1997), "The Relationship between Strategic Purchasing and Customer Satisfaction within a Total Quality Management Environment", Benchmarking for Quality Management \& Technology, Vol. 4 No. 4, pp. 244-258.

Brown, D., O’Dea, F., Schul, H.L. and Hintlian, J. (2015), “Infinite Possibilities: Procurement in 2025", Ernst \& Young LLP, available at: http://www.ey.com/Publication/vwLUAssets/EY-infinite-possibilities-procurement-in2025/\$FILE/EY-infinite-possibilities-procurement-in-2025.pdf (accessed 2 July 2018).

Caddick, J. r. and Dale, B. g. (1987), "The Determination of Purchasing Objectives and Strategies: Some Key Influences", International Journal of Physical Distribution \& Materials Management, Vol. 17 No. 3, pp. 5-16.

Carr, A.S., Keong Leong, G. and Sheu, C. (2000), “A Study of Purchasing Practices in Taiwan”, International Journal of Operations \& Production Management, Vol. 20 No. 12, pp. 14271446.

Carr, A.S. and Pearson, J.N. (1999), "Strategically Managed Buyer-supplier Relationships and Performance Outcomes", Journal of Operations Management, Vol. 17 No. 5, pp. 497-519.

Carr, A.S. and Pearson, J.N. (2002), "The Impact of Purchasing and Supplier Involvement on Strategic Purchasing and its Impact on Firm's Performance", International Journal of Operations \& Production Management, Vol. 22 No. 9, pp. 1032-1053.

Carr, A.S. and Smeltzer, L.R. (1997), "An Empirically Based Operational Definition of Strategic Purchasing”, European Journal of Purchasing \& Supply Management, Vol. 3 No. 4, pp. 199-207.

Carr, A.S. and Smeltzer, L.R. (1999a), "The Relationship Among Purchasing Benchmarking, Strategic Purchasing, Firm Performance, and Firm Size", Journal of Supply Chain Management, Vol. 35 No. 4, pp. 51-60.

Carr, A.S. and Smeltzer, L.R. (1999b), "The Relationship of Strategic Purchasing to Supply Chain Management", European Journal of Purchasing \& Supply Management, Vol. 5 No. 1, pp. 43-51. 
Carr, A.S. and Smeltzer, L.R. (2000), "An Empirical Study of the Relationships among Purchasing Skills and Strategic Purchasing, Financial Performance, and Supplier Responsiveness", Journal of Supply Chain Management, Vol. 36 No. 2, pp. 40-54.

Castaldi, C., Kate, C. ten and Braber, R. den. (2011), "Strategic Purchasing and Innovation: A Relational View", Technology Analysis \& Strategic Management, Vol. 23 No. 9, pp. 9831000 .

Cavinato, J.L. (1999), "Fitting Purchasing to the Five Stages of Strategic Management", European Journal of Purchasing \& Supply Management, Vol. 5 No. 2, pp. 75-83.

Chen, I.J., Paulraj, A. and Lado, A.A. (2004), "Strategic Purchasing, Supply Management, and Firm Performance", Journal of Operations Management, Vol. 22 No. 5, pp. 505-523.

Cousins, P.D. (2005), "The Alignment of Appropriate Firm and Supply Strategies for Competitive Advantage", International Journal of Operations \& Production Management, Vol. 25 No. 5/6, pp. 403-428.

Cousins, P.D., Lamming, R.C. and Bowen, F. (2004), "The Role of Risk in Environment-related Supplier Initiatives", International Journal of Operations \& Production Management, Vol. 24 No. 6, pp. 554-565.

Cousins, P.D., Lawson, B. and Squire, B. (2006), "An Empirical Taxonomy of Purchasing Functions", International Journal of Operations \& Production Management, Vol. 26 No. 7, pp. $775-794$.

Chan, T.C.T. and Chin, K. (2007), "Key Success Factors of Strategic Sourcing: An Empirical Study of the Hong Kong Toy Industry", Industrial Management \& Data Systems, Vol. 107 No. 9, pp. 1391-1416.

Chan, T.C., Chin, K. and Lam, P. (2007), "Strategic Sourcing in the Hong Kong Toy Industry", International Journal of Quality \& Reliability Management, Vol. 24 No. 8, pp. 776-799.

Chiang, C., Kocabasoglu $\square$ Hillmer, C. and Suresh, N. (2012), "An Empirical Investigation of the Impact of Strategic Sourcing and Flexibility on Firm's Supply Chain Agility", International Journal of Operations \& Production Management, Vol. 32 No. 1, pp. 49-78.

Christodoulidou, N., Leong, G.K. and Raab, C. (2012), "Strategic Sourcing in the Hospitality Supply Chain”, Journal of Foodservice Business Research, Vol. 15 No. 2, pp. 143-155.

David, J.S., Hwang, Y., Pei, B.K.W. and Reneau, J.H. (2002), "The Performance Effects of Congruence Between Product Competitive Strategies and Purchasing Management Design", Management Science, Vol. 48 No. 7, pp. 866-885.

Day, M. and Lichtenstein, S. (2006), "Strategic Supply Management: The Relationship Between Supply Management Practices, Strategic Orientation and Their Impact on Organisational Performance", Journal of Purchasing \& Supply Management, Vol. 12 No. 6, pp. 313-321.

Deasy, M., White, G.R.T., Parfitt, S. and Ringwald, K. (2014), “Asymmetric Procurement in the Public Sector”, Strategic Change, Vol. 23 No. 1-2, pp. 21-29. 
Donaldson, L. (2001), The Contingency Theory of Organizations, 1st ed., SAGE Publications, Incorporated, Thousand Oaks, Calif.

Dyer, J.H. and Singh, H. (1998), "The Relational View: Cooperative Strategy and Sources of Interorganizational Competitive Advantage”, Academy of Management Review, Vol. 23 No. 4, pp. 660-679.

Eisenhardt, K.M. (1989), "Building Theories from Case Study Research", The Academy of Management Review, Vol. 14 No. 4, pp. 532-550.

Ellram, L.M. and Carr, A. (1994), "Strategic Purchasing: A History and Review of the Literature", International Journal of Purchasing and Materials Management, Vol. 30 No. 2, pp. 10-18.

Ellram, L.M., Zsidisin, G.A., Siferd, S.P. and Stanly, M.J. (2002), "The Impact of Purchasing and Supply Management Activities on Corporate Success", Journal of Supply Chain Management, Vol. 38 No. 1, pp. 4-17.

Eltantawy, R.A. and Giunipero, L. (2013), "An Empirical Examination of Strategic Sourcing Dominant Logic: Strategic Sourcing Centricity", Journal of Purchasing and Supply Management, Vol. 19 No. 4, pp. 215-226.

Eltantawy, R., Giunipero, L. and Handfield, R. (2014), "Strategic Sourcing Management's Mindset: Strategic Sourcing Orientation and its Implications", International Journal of Physical Distribution \& Logistics Management, Vol. 44 No. 10, pp. 768-795.

Farmer, D. (1981), "Developing Purchasing Strategies", International Journal of Physical Distribution \& Materials Management, Vol. 11 No. 2/3, pp. 114-121.

Foerstl, K., Hartmann, E., Wynstra, F. and Moser, R. (2013), “Cross-functional Integration and Functional Coordination in Purchasing and Supply Management: Antecedents and Effects on Purchasing and Firm Performance", International Journal of Operations \& Production Management, Vol. 33 No. 6, pp. 689-721.

Freeman, V.T. and Cavinato, J.L. (1990), "Fitting Purchasing To The Strategic Firm: Frameworks, Processes, and Values", Journal of Purchasing \& Materials Management, Vol. 26 No. 1, pp. 6-10.

González-Benito, J. (2007), “A Theory of Purchasing's Contribution to Business Performance”, Journal of Operations Management, Vol. 25 No. 4, pp. 901-917.

Handfield, R.B., Cousins, P.D., Lawson, B. and Petersen, K.J. (2015), "How Can Supply Management Really Improve Performance? A Knowledge-Based Model of Alignment Capabilities", Journal of Supply Chain Management, Vol. 51 No. 3, pp. 3-17.

Hartmann, A., Roehrich, J., Frederiksen, L. and Davies, A. (2014), "Procuring Complex Performance: The Transition Process in Public Infrastructure", International Journal of Operations \& Production Management, Vol. 34 No. 2, pp. 174-194. 
Hartmann, E., Kerkfeld, D. and Henke, M. (2012), "Top and Bottom Line Relevance of Purchasing and Supply Management”, Journal of Purchasing \& Supply Management, Vol. 18 No. 1, pp. 22-34.

Hesping, F.H. and Schiele, H. (2015), "Purchasing Strategy Development: A Multi-level Review", Journal of Purchasing \& Supply Management, Vol. 21 No. 2, pp. 138-150.

Huang, Y.-Y. and Handfield, R.B. (2015), "Measuring the Benefits of ERP on Supply Management Maturity Model: A 'Big Data' Method', International Journal of Operations \& Production Management, Vol. 35 No. 1, pp. 2-25.

Izquierdo, C.C., Samaniego, M.J.G. and Cabezudo, R.S.J. (2015), "How Strategic Purchasing Orientation and Transformational Leadership Impact Performance: The Mediating Role of Information and Communication Technologies", Journal of Business-to-Business Marketing, Vol. 22 No. 4, pp. 269-292.

Kaufmann, L. and Gaeckler, J. (2015), “On the Relationship Between Purchasing Integration and Purchasing Decision-making Speed", International Journal of Physical Distribution \& Logistics Management, Vol. 45 No. 3, pp. 214-236.

Keough, M. (1993), "Buying Your Way to the Top", McKinsey Quarterly, August, No. 3, pp. $41-62$.

Khan K, A. and Pillania, R.K. (2008), "Strategic Sourcing for Supply Chain Agility and Firms' Performance: A Study of Indian Manufacturing Sector", Management Decision, Vol. 46 No. 10, pp. 1508-1530.

Kim, M. and Chai, S. (2017), "The Impact of Supplier Innovativeness, Information Sharing and Strategic Sourcing on Improving Supply Chain Agility: Global Supply Chain Perspective", International Journal of Production Economics, Vol. 187, pp. 42-52.

Kim, M., Suresh, N.C. and Kocabasoglu-Hillmer, C. (2015), "A Contextual Analysis of the Impact of Strategic Sourcing and E-procurement on Performance", Journal of Business \& Industrial Marketing, Vol. 30 No. 1, pp. 1-16.

King, N. (2012), "Doing Template Analysis", Simon, Gillian and Catherine Cassell (Eds.): Qualitative Organizational Research: Core Methods and Current Challenges, Sage Publications Ltd, London, pp. 426-450.

Knoppen, D. and Sáenz, M.J. (2015), "Purchasing: Can We Bridge the Gap Between Strategy and Daily Reality?”, Business Horizons, Vol. 58 No. 1, pp. 123-133.

Kocabasoglu, C. and Suresh, N.C. (2006), "Strategic Sourcing: An Empirical Investigation of the Concept and Its Practices in U.S. Manufacturing Firms", Journal of Supply Chain Management, Vol. 42 No. 2, pp. 4-16.

Kraljic, P. (1983), "Purchasing Must Become Supply Management”, Harvard Business Review, Vol. 61 No. 5, pp. 109-117. 
Kroes, J.R. and Ghosh, S. (2010), "Outsourcing Congruence with Competitive Priorities: Impact on Supply Chain and Firm Performance", Journal of Operations Management, Vol. 28 No. 2, pp. 124-143.

Lawson, B., Cousins, P.D., Handfield, R.B. and Petersen, K.J. (2009), "Strategic Purchasing, Supply Management Practices and Buyer Performance Improvement: An Empirical Study of UK Manufacturing Organisations”, International Journal of Production Research, Vol. 47 No. 10 , pp. 2649-2667.

Lee, P.K.C. and Humphreys, P.K. (2007), "The Role of Guanxi in Supply Management Practices", International Journal of Production Economics, Vol. 106 No. 2, pp. 450-467.

van Lith, J., Voordijk, H., Matos Castano, J. and Vos, B. (2015), "Assessing Maturity Development of Purchasing Management in Construction", Benchmarking: An International Journal, Vol. 22 No. 6, pp. 1033-1057.

Loppacher, J.S. (2006), “Global Sourcing And Procurement Strategy: A Model Of Interrelated Decisions", Supply Chain Forum, Vol. 7 No. 12, pp. 34-46.

Luzzini, D., Longoni, A., Moretto, A., Caniato, F. and Brun, A. (2014), “Organizing IT Purchases: Evidence From a Global Study", Journal of Purchasing \& Supply Management, Vol. 20 No. 3, pp. 143-155.

Luzzini, D. and Ronchi, S. (2016), "Cinderella Purchasing Transformation: Linking Purchasing Status to Purchasing Practices and Business Performance”, Production Planning \& Control, Vol. 27 No. 10, pp. 787-796.

Matthews, D. (2005), "Strategic Procurement in the Public Sector: A Mask for Financial and Administrative Policy”, Journal of Public Procurement, Vol. 5 No. 3, pp. 388-399.

Mikalef, P., Batenburg, R., Pateli, A. and van de Wetering, R. (2014), "Business Alignment in the Procurement Domain: A Study of Antecedents and Determinants of Supply Chain Performance", International Journal of Information Systems and Project Management, Vol. 2 No. 1, pp. 43-59.

Mikalef, P., Pateli, A., Batenburg, R.S. and van de Wetering, R. (2015), "Purchasing Alignment Under Multiple Contingencies: A Configuration Theory Approach", Industrial Management \& Data Systems, Vol. 115 No. 4, pp. 625-645.

Miles, R.E. and Snow, C.C. (1984), "Fit, Failure and the Hall of Fame", California Management Review, Vol. 26 No. 3, pp. 10-28.

Monczka, R.M. and Trent, R.J. (1991), "Global Sourcing: A Development Approach", International Journal of Purchasing \& Materials Management, Vol. 27 No. 2, pp. 2-8.

Mpeera Ntayi, J. and Mugume, E. (2014), "A Taxonomy of Strategic Sourcing for Defense Forces in Sub-Saharan Africa", World Journal of Entrepreneurship, Management and Sustainable Development, Vol. 10 No. 1, pp. 13-32. 
Narasimhan, R. and Carter, J.R. (1998), "Linking Business Unit and Material Sourcing Strategies", Journal of Business Logistics, Vol. 19 No. 2, pp. 155-171.

Narasimhan, R. and Das, A. (2001), "The Impact of Purchasing Integration and Practices on Manufacturing Performance", Journal of Operations Management, Vol. 19 No. 5, pp. $593-$ 609.

Ogden, J.A., Rossetti, C.L. and Hendrick, T.E. (2007), “An Exploratory Cross-country Comparison of Strategic Purchasing", Journal of Purchasing \& Supply Management, Vol. 13 No. 1, pp. 2-16.

Paik, S.-K., Bagchi, P.K., Skjøtt-Larsen, T. and Adams, J. (2009), "Purchasing Development in Small and Medium-Sized Enterprises (SMEs)", Supply Chain Forum, Vol. 10 No. 18, pp. 91-107.

Paulraj, A. (2011), "Understanding the Relationships Between Internal Resources and Capabilities, Sustainable Supply Management and Organizational Sustainability", Journal of Supply Chain Management, Vol. 47 No. 1, pp. 19-37.

Paulraj, A. and Chen, I.J. (2005), "Strategic Supply Management and Dyadic Quality Performance: A Path Analytical Model”, Journal of Supply Chain Management, Vol. 41 No. 3, pp. 4-18.

Paulraj, A. and Chen, I.J. (2007), "Environmental Uncertainty and Strategic Supply Management: A Resource Dependence Perspective and Performance Implications", Journal of Supply Chain Management, Vol. 43 No. 3, pp. 29-42.

Paulraj, A., Chen, I.J. and Flynn, J. (2006), "Levels of Strategic Purchasing: Impact on Supply Integration and Performance", Journal of Purchasing \& Supply Management, Vol. 12 No. 3, pp. 107-122.

Pearson, J.N. and Gritzmacher, K.J. (1990), "Integrating Purchasing into Strategic Management”, Long Range Planning, Vol. 23 No. 3, pp. 91-99.

Pettigrew, A. (1988) Longitudinal field research on change: Theory and practice. Paper presented at the National Science Foundation Conference on Longitudinal Research Methods in Organizations, Austin.

Pohl, M. and Förstl, K. (2011), "Achieving Purchasing Competence through Purchasing Performance Measurement System Design - A Multiple-case Study Analysis”, Journal of Purchasing \& Supply Management, Vol. 17 No. 4, pp. 231-245.

Pongsuwan, P. (2016), "How Does Procurement Capability Maturity Affect E-Procurement Adoption and Leverage Purchasing in Supply Chain", International Journal of Business and Economic Development, Vol. 4 No. 3, pp. 45-54.

Pressey, A., Tzokas, N. and Winklhofer, H. (2007), "Strategic Purchasing and the Evaluation of 'Problem' Key Supply Relationships: What Do Key Suppliers Need to Know?", Journal of Business \& Industrial Marketing, Vol. 22 No. 4/5, pp. 282-294. 
Pressey, A.D., Winklhofer, H.M. and Tzokas, N.X. (2009), "Purchasing Practices in Small- to Medium-sized Enterprises: An Examination of Strategic Purchasing Adoption, Supplier Evaluation and Supplier Capabilities", Journal of Purchasing \& Supply Management, Vol. 15 No. 4, pp. 214-226.

Prida, B. and Gutierrez, G. (1996), "Supply Management: From Purchasing to External Factory Management", Production \& Inventory Management Journal; Alexandria, Vol. 37 No. 4, pp. $38-43$.

Quayle, M. (1998), “The Impact of Strategic Procurement in the UK Government Sector", International Journal of Public Sector Management, Vol. 11 No. 5, p. 397.

Quayle, M. and Quayle, S. (2000), “The Impact of Strategic Procurement in the UK Further and Higher Education Sectors”, International Journal of Public Sector Management, Vol. 13 No. 3, pp. $260-284$.

Rajagopal, S. and Bernard, K.N. (1993a), "Strategic Procurement and Competitive Advantage", International Journal of Purchasing and Materials Management, Vol. 29 No. 3, pp. 12-20.

Rajagopal, S. and Bernard, K.N. (1993b), "Globalization of the Procurement Process", Marketing Intelligence \& Planning, Vol. 11 No. 7, pp. 44-56.

Rebolledo, C. and Jobin, M.-H. (2013), "Manufacturing and Supply Alignment: Are Different Manufacturing Strategies Linked to Different Purchasing Practices?", International Journal of Production Economics, Vol. 146 No. 1, pp. 219-226.

Reck, R.F. and Long, B.G. (1988), "Purchasing: A Competitive Weapon", Journal of Purchasing \& Materials Management, Vol. 24 No. 3, pp. 2-8.

Rendon, R.G. (2008), "Procurement Process Maturity: Key to Performance Measurement", Journal of Public Procurement, Vol. 8 No. 2, pp. 200-214.

Revilla, E. and Knoppen, D. (2015), "Building Knowledge Integration in Buyer-supplier Relationships: The Critical Role of Strategic Supply Management and Trust", International Journal of Operations \& Production Management, Vol. 35 No. 10, pp. 1408-1436.

Rossetti, C.L. and Choi, T.Y. (2005), "On the Dark Side of Strategic Sourcing: Experiences from the Aerospace Industry”, Academy of Management Executive, Vol. 19 No. 1, pp. 4660 .

Rozemeijer, F.A., van Weele, A. and Weggeman, M. (2003), "Creating Corporate Advantage through Purchasing: Toward a Contingency Model", Journal of Supply Chain Management, Vol. 39 No. 1, pp. 4-13.

Rozemeijer, F.A. and van Weele, A.J. (1998), "Professionalising Purchasing in Organisation: Toward a Purchasing Development Model", presented at the Seventh International IPSERA Conference, Gerco Rietveld, London, pp. 515-523. 
Sánchez-Rodríguez, C. (2009), "Effect of Strategic Purchasing on Supplier Development and Performance: A Structural Model”, Journal of Business \& Industrial Marketing, Vol. 24 No. 3/4, pp. 161-172.

Schiele, H. (2007), "Supply-Management Maturity, Cost Savings and Purchasing Absorptive Capacity: Testing the Procurement-Performance Link", Journal of Purchasing \& Supply Management, Vol. 13 No. 4, pp. 274-293.

Spekman, R.E. (1989), “A Strategic Approach to Procurement Planning”, Journal of Purchasing \& Materials Management, Vol. 25 No. 1, pp. 3-10.

Spekman, R.E. and Hill, R. (1980), "Strategy for Effective Procurement in the 1980s", Journal of Purchasing \& Materials Management, Vol. 16 No. 1, pp. 2-6.

$\mathrm{Su}$, J. (2013), "Strategic Sourcing in the Textile and Apparel Industry", Industrial Management \& Data Systems, Vol. 113 No. 1, pp. 23-38.

Su, J. and Gargeya, V.B. (2012), "Strategic Sourcing, Sourcing Capability and Firm Performance in the US Textile and Apparel Industry", Strategic Outsourcing: An International Journal, Vol. 5 No. 2, pp. 145-165.

Tassabehji, R. and Moorhouse, A. (2008), "The Changing Role of Procurement: Developing Professional Effectiveness", Journal of Purchasing \& Supply Management, Vol. 14 No. 1, pp. 55-68.

Tranfield, D., Denyer, D. and Smart, P. (2003), "Towards a Methodology for Developing Evidence-Informed Management Knowledge by Means of Systematic Review", British Journal of Management, Vol. 14 No. 3, pp. 207-222.

Trent, R.J. and Monczka, R.M. (2002), "Pursuing Competitive Advantage through Integrated Global Sourcing", The Academy of Management Executive, Vol. 16 No. 2, pp. 66-80.

Trim, P.R.J. (2005), "The Integrated Strategic Purchasing and Focused Outsourcing Approach", Strategic Change, Vol. 14 No. 7, pp. 381-390.

Úbeda, R., Alsua, C. and Carrasco, N. (2015), "Purchasing Models and Organizational Performance: A Study of Key Strategic Tools", Journal of Business Research, Vol. 68 No. 2, pp. $177-188$.

Versendaal, J., Akker, M. van den, Xing, X. and Bevere, B. de. (2013), "Procurement Maturity and IT-alignment Models: Overview and a Case Study”, Electronic Markets, Vol. 23 No. 4, pp. 295-306.

Watson, R., Wilson, H., MacDonald, E. and Smart, P. (2015), "Engaging Stakeholders in Innovation for Environmental Sustainability: A Capability-Based Framework", Academy of Management Proceedings, Vol. 2015 No. 1, p. 14662.

Watts, C.A., Kim, K.Y. and Hahn, C.K. (1992), "Linking Purchasing to Corporate Competitive Strategy”, International Journal of Purchasing \& Materials Management, Vol. 31 No. 2, pp. $2-8$. 
White, G.R.T., Parfitt, S., Lee, C. and Mason-Jones, R. (2016), "Challenges to the Development of Strategic Procurement: A Meta-Analysis of Organizations in the Public and Private Sectors", Strategic Change, Vol. 25 No. 3, pp. 285-298.

Wong, C., Skipworth, H., Godsell, J. and Achimugu, N. (2012), "Towards a Theory of Supply Chain Alignment Enablers: A Systematic Literature Review", Supply Chain Management: An International Journal, Vol. 17 No. 4, pp. 419-437.

Yavas, U., Luqmani, M. and Quraeshi, Z.A. (1989), "Purchasing Efficacy in an Arabian Gulf Country", International Journal of Physical Distribution \& Materials Management, Vol. 19 No. 4, pp. 20-25.

Yeung, A.C.L. (2008), "Strategic Supply Management, Quality Initiatives, and Organizational Performance”, Journal of Operations Management, Vol. 26 No. 4, pp. 490-502.

Yeung, K., Cheng, T.C.E. and Lee, P.K.C. (2015), "Buyers' Perceptions on the Impact of Strategic Purchasing on Dyadic Quality Performances", International Journal of Production Economics, Vol. 168, pp. 321-330.

Yin, R.K. (1994), Case Study Research: Design and Methods, 1st ed., SAGE Publications, Inc, Thousand Oaks.

Zsidisin, G.A. and Ellram, L.M. (2001), "Activities Related to Purchasing and Supply Management Involvement in Supplier Alliances", International Journal of Physical Distribution \& Logistics Management, Vol. 31 No. 9, pp. 629-646. 
Table 1: Selection criteria (adapted from Watson et al., 2015)

\begin{tabular}{|c|c|c|c|}
\hline Criteria & Inclusion & Exclusion & Rationale \\
\hline Context & $\begin{array}{l}\text { Articles in the context of } \\
\text { purchasing maturity and } \\
\text { purchasing alignment }\end{array}$ & $\begin{array}{l}\text { Articles focusing on topics such as } \\
\text { consumer buying, IT, mergers and } \\
\text { acquisitions, engineering, governance, } \\
\text { banking, innovation, project } \\
\text { management, sociology, marketing, } \\
\text { HR, etc. }\end{array}$ & $\begin{array}{l}\text { To ensure articles support } \\
\text { answering research } \\
\text { question }\end{array}$ \\
\hline \multirow{2}{*}{$\begin{array}{c}\text { Topical fit: } \\
\text { Purchasing maturity }\end{array}$} & \multirow{2}{*}{$\begin{array}{l}\text { Papers on purchasing } \\
\text { maturity models, including } \\
\text { maturity models that focus } \\
\text { on a single capability (e.g. } \\
\text { global sourcing) }\end{array}$} & $\begin{array}{l}\text { Supply chain management with focus } \\
\text { other than purchasing (e.g. planning } \\
\text { or logistics), or focusing on a special } \\
\text { aspect of purchasing without } \\
\text { reference to maturity models }\end{array}$ & \multirow{2}{*}{$\begin{array}{l}\text { To ensure articles support } \\
\text { answering research } \\
\text { question }\end{array}$} \\
\hline & & $\begin{array}{l}\text { Maturity models that focus on } \\
\text { supporting aspects that are not } \\
\text { capabilities (e.g. IT systems for } \\
\text { purchasing) }\end{array}$ & \\
\hline $\begin{array}{c}\text { Topical fit: } \\
\text { Alignment } \\
\text { conceptualisation }\end{array}$ & $\begin{array}{l}\text { Strategic (vertical) alignment } \\
\text { between purchasing strategy } \\
\text { and firm strategy, including } \\
\text { strategic purchasing papers } \\
\text { conceptualising purchasing } \\
\text { without alignment }\end{array}$ & $\begin{array}{l}\text { Integration (horizontal alignment), } \\
\text { network alignment (e.g. with } \\
\text { suppliers) }\end{array}$ & $\begin{array}{l}\text { To ensure articles support } \\
\text { answering research } \\
\text { question }\end{array}$ \\
\hline Publication type & $\begin{array}{l}\text { Peer-reviewed, scholarly and } \\
\text { academic papers }\end{array}$ & $\begin{array}{l}\text { Non-scholarly articles, newspapers, } \\
\text { trade publications, magazines and } \\
\text { proceedings, working papers, theses, } \\
\text { books }\end{array}$ & $\begin{array}{l}\text { To ensure methodical } \\
\text { rigour and } \\
\text { comprehensiveness }\end{array}$ \\
\hline Date of publication & All & None & $\begin{array}{l}\text { To include development } \\
\text { of core concepts over time }\end{array}$ \\
\hline Language & English & All other languages & $\begin{array}{l}\text { To avoid errors in } \\
\text { translation }\end{array}$ \\
\hline Sector / industry & All & None & $\begin{array}{l}\text { To include differences } \\
\text { between industries and } \\
\text { avoid bias }\end{array}$ \\
\hline Research method & All & None & To avoid bias \\
\hline
\end{tabular}


Table 2: Search string results by process step

\begin{tabular}{|c|c|c|c|c|c|}
\hline Search string & \multicolumn{2}{|c|}{ Purchasing maturity } & \multicolumn{2}{|c|}{$\begin{array}{l}\text { Purchasing alignment or } \\
\text { strategic purchasing }\end{array}$} & \multirow{2}{*}{ Total } \\
\hline Database & EBSCO & ABI & EBSCO & ABI & \\
\hline Initial results & 1,281 & 1,088 & 1,023 & 811 & 4,203 \\
\hline Title and abstract screening & 49 & 43 & 153 & 133 & 378 \\
\hline \multicolumn{5}{|l|}{ Remove duplicates } & 240 \\
\hline \multicolumn{5}{|c|}{ Full text screening (papers taken forward to analysis) } & 87 \\
\hline \multicolumn{5}{|c|}{ Additional papers through reference search } & 17 \\
\hline \multicolumn{5}{|l|}{ Total papers considered } & 104 \\
\hline
\end{tabular}


Table 3: Case study overview

\begin{tabular}{|l|c|c|c|c|}
\hline Case attribute & BANK & FOOD & CAR & DRINK \\
\hline Industry & $\begin{array}{c}\text { Banking, Financial } \\
\text { Services }\end{array}$ & $\begin{array}{c}\text { Food \& Drinks } \\
\text { Manufacturing }\end{array}$ & Automotive Aftermarket & $\begin{array}{c}\text { Food \& Drinks } \\
\text { Manufacturing }\end{array}$ \\
\hline Founding Year [Range] & Before 1900 & Before 1900 & Before 1900 & Before 1900 \\
\hline $\begin{array}{l}\text { Size (Employees) } \\
\text { [Range] }\end{array}$ & $>100,000$ & $>100,000$ & $10,000-50,000$ & $<10,000$ \\
\hline Turnover [Range] & $>£ 10 \mathrm{bn}$ & $>£ 10 \mathrm{bn}$ & $<£ 5 \mathrm{bn}$ & $<£ 5 \mathrm{bn}$ \\
\hline Market competitiveness & Very competitive & Somewhat competitive & Limited competition & Somewhat competitive \\
\hline Market position & Market leader & Market leader & Market leader & Large follower \\
\hline $\begin{array}{l}\text { Degree of technological } \\
\text { disruption }\end{array}$ & $\begin{array}{c}\text { High level of } \\
\text { technological disruption }\end{array}$ & $\begin{array}{c}\text { Medium technological } \\
\text { disruption }\end{array}$ & $\begin{array}{c}\text { Low disruption (high } \\
\text { expectation of future } \\
\text { disruption) }\end{array}$ & $\begin{array}{c}\text { Medium technological } \\
\text { disruption }\end{array}$ \\
\hline Strategy classification & Cost leadership & Differentiation & Differentiation & Differentiation \\
\hline
\end{tabular}


Table 4: Sample coding structure for interviews

\begin{tabular}{|c|c|c|c|c|}
\hline Topic & $\begin{array}{l}\text { First order } \\
\text { construct }\end{array}$ & $\begin{array}{l}\text { Second order } \\
\text { construct }\end{array}$ & Description & References \\
\hline \multirow[t]{13}{*}{$\begin{array}{l}\text { Purchasing } \\
\text { strategy } \\
\text { contingencies }\end{array}$} & \multirow[t]{4}{*}{$\begin{array}{l}\text { Internal or } \\
\text { firm driven } \\
\text { contingencies }\end{array}$} & Firm strategy & $\begin{array}{l}\text { Comments around the purchasing strategy } \\
\text { being based on and/or in alignment with the } \\
\text { company strategy }\end{array}$ & BANK \\
\hline & & $\begin{array}{l}\text { Corporate } \\
\text { principles }\end{array}$ & $\begin{array}{l}\text { Comments around the purchasing strategy } \\
\text { being based on and/or in alignment with } \\
\text { corporate principles or governance }\end{array}$ & FOOD \\
\hline & & Firm culture & $\begin{array}{l}\text { Comments around the purchasing strategy } \\
\text { being based on and/or in alignment with the } \\
\text { firm culture or ways of working }\end{array}$ & CAR \\
\hline & & $\begin{array}{l}\text { Stakeholder and } \\
\text { business } \\
\text { requirements }\end{array}$ & $\begin{array}{l}\text { Comments around the purchasing strategy } \\
\text { being based on and/or in alignment with } \\
\text { stakeholder and/or business requirements }\end{array}$ & DRINK \\
\hline & \multirow[t]{3}{*}{$\begin{array}{l}\text { External or } \\
\text { demand driven } \\
\text { contingencies }\end{array}$} & $\begin{array}{l}\text { Geopolitical } \\
\text { changes }\end{array}$ & $\begin{array}{l}\text { Comments around the purchasing strategy } \\
\text { being based on and/or in alignment with } \\
\text { changes in global politics }\end{array}$ & BANK \\
\hline & & $\begin{array}{l}\text { Customer or } \\
\text { demand }\end{array}$ & $\begin{array}{l}\text { Comments around the purchasing strategy } \\
\text { being based on and/or in alignment with } \\
\text { customer requirements or demand } \\
\text { characteristics }\end{array}$ & CAR, FOOD \\
\hline & & $\begin{array}{l}\text { Industry specifics } \\
\text { or requirements }\end{array}$ & $\begin{array}{l}\text { Comments around the purchasing strategy } \\
\text { being based on and/or in alignment with } \\
\text { industry characteristics }\end{array}$ & $\begin{array}{l}\text { BANK, CAR, } \\
\text { FOOD }\end{array}$ \\
\hline & \multirow[t]{2}{*}{$\begin{array}{l}\text { Technological } \\
\text { contingencies }\end{array}$} & $\begin{array}{l}\text { Systems } \\
\text { vulnerability }\end{array}$ & $\begin{array}{l}\text { Comments around the purchasing strategy } \\
\text { being based on and/or in alignment with the } \\
\text { vulnerability of existing IT infrastructure }\end{array}$ & BANK \\
\hline & & Technology trends & $\begin{array}{l}\text { Comments around the purchasing strategy } \\
\text { being based on and/or in alignment with } \\
\text { current technology trends }\end{array}$ & DRINK, FOOD \\
\hline & \multirow[t]{4}{*}{$\begin{array}{l}\text { Product or } \\
\text { supply driven } \\
\text { contingencies }\end{array}$} & $\begin{array}{l}\text { Current } \\
\text { contractual } \\
\text { arrangements }\end{array}$ & $\begin{array}{l}\text { Comments around the purchasing strategy } \\
\text { being based on and/or in alignment with the } \\
\text { supplier contracts in place }\end{array}$ & DRINK \\
\hline & & $\begin{array}{l}\text { Product } \\
\text { characteristics }\end{array}$ & $\begin{array}{l}\text { Comments around the purchasing strategy } \\
\text { being based on and/or in alignment with the } \\
\text { product characteristics (e.g. complexity, } \\
\text { quality) }\end{array}$ & CAR \\
\hline & & Supplier market & $\begin{array}{l}\text { Comments around the purchasing strategy } \\
\text { being based on and/or in alignment with } \\
\text { supplier market characteristics }\end{array}$ & $\begin{array}{l}\text { BANK, DRINK, } \\
\text { FOOD, CAR }\end{array}$ \\
\hline & & $\begin{array}{l}\text { Future product } \\
\text { development }\end{array}$ & $\begin{array}{l}\text { Comments around the purchasing strategy } \\
\text { being based on and/or in alignment with } \\
\text { future product development requirements }\end{array}$ & DRINK \\
\hline \multirow{4}{*}{$\begin{array}{l}\text { Purchasing } \\
\text { maturity } \\
\text { practice } \\
\text { contingencies }\end{array}$} & \multirow[t]{3}{*}{$\begin{array}{l}\text { Internal or } \\
\text { firm driven } \\
\text { contingencies }\end{array}$} & Company size & $\begin{array}{l}\text { Comments around the selection of } \\
\text { purchasing practices being influenced by the } \\
\text { company size }\end{array}$ & BANK \\
\hline & & Company culture & $\begin{array}{l}\text { Comments around the selection of } \\
\text { purchasing practices being influenced by the } \\
\text { company culture or ways of working }\end{array}$ & DRINK \\
\hline & & $\begin{array}{l}\text { Stakeholder and } \\
\text { business } \\
\text { requirements }\end{array}$ & $\begin{array}{l}\text { Comments around the selection of } \\
\text { purchasing practices being influenced by } \\
\text { stakeholder and/or business requirements }\end{array}$ & DRINK \\
\hline & $\begin{array}{l}\text { External or } \\
\text { demand driven } \\
\text { contingencies }\end{array}$ & $\begin{array}{l}\text { Industry specifics } \\
\text { or requirements }\end{array}$ & $\begin{array}{l}\text { Comments around the selection of } \\
\text { purchasing practices being influenced by } \\
\text { industry characteristics }\end{array}$ & BANK, CAR \\
\hline
\end{tabular}




\begin{tabular}{|c|c|c|c|c|}
\hline \multirow[t]{5}{*}{ Topic } & \multirow[t]{3}{*}{$\begin{array}{l}\text { First order } \\
\text { construct }\end{array}$} & $\begin{array}{l}\text { Second order } \\
\text { construct }\end{array}$ & Description & References \\
\hline & & $\begin{array}{l}\text { Benchmarks from } \\
\text { competitors }\end{array}$ & $\begin{array}{l}\text { Comments around the selection of } \\
\text { purchasing practices being influenced by } \\
\text { competitor behaviour }\end{array}$ & DRINK \\
\hline & & Consulting advice & $\begin{array}{l}\text { Comments around the selection of } \\
\text { purchasing practices being influenced by } \\
\text { advice from consultancies }\end{array}$ & BANK \\
\hline & \multirow[t]{2}{*}{$\begin{array}{l}\text { Product or } \\
\text { supply driven } \\
\text { contingencies }\end{array}$} & $\begin{array}{l}\text { Product } \\
\text { characteristics }\end{array}$ & $\begin{array}{l}\text { Comments around the selection of } \\
\text { purchasing practices being influenced by } \\
\text { product characteristics (e.g. complexity, } \\
\text { quality) }\end{array}$ & CAR \\
\hline & & Supplier market & $\begin{array}{l}\text { Comments around the selection of } \\
\text { purchasing practices being influenced by } \\
\text { supplier market characteristics }\end{array}$ & BANK \\
\hline
\end{tabular}


Figure 1: Descriptive analysis of academic papers (Note: Some papers cover more than one topic)

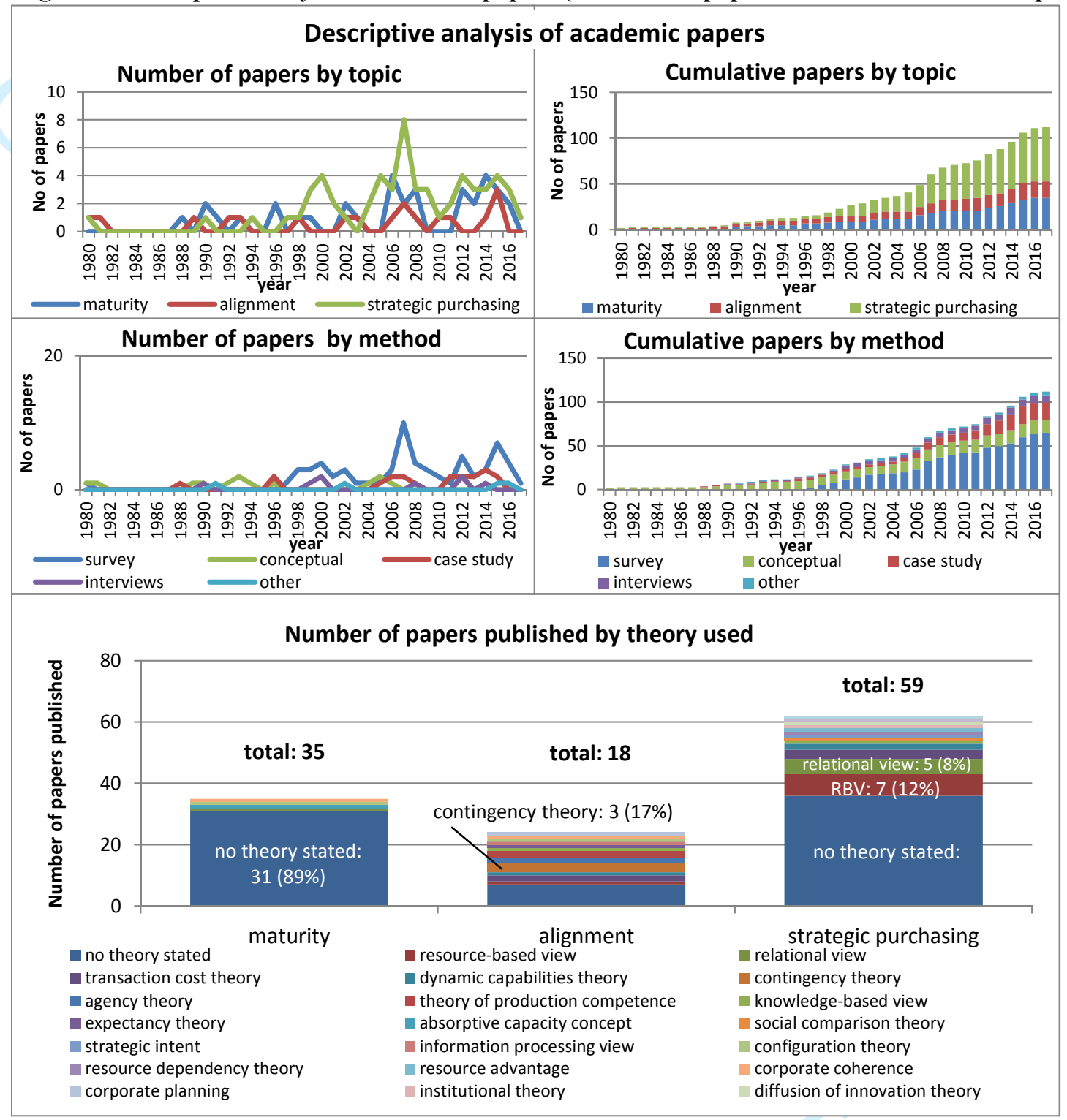


Table 5: Academic papers findings summary (note, some papers cover more than one topic and finding type)

\begin{tabular}{|c|c|c|c|}
\hline $\begin{array}{l}\text { Findings summary \& } \\
\text { number of papers }\end{array}$ & Alignment & Strategic purchasing & Maturity \\
\hline $\begin{array}{l}\text { Development and testing } \\
\text { of frameworks and } \\
\text { concepts }\end{array}$ & $\begin{array}{l}\text { Development and testing of a } \\
\text { framework for purchasing } \\
\text { strategic alignment ( } 12 \\
\text { papers; } 67 \% \text { of strategic } \\
\text { alignment papers) }\end{array}$ & $\begin{array}{l}\text { Review of strategic } \\
\text { purchasing concept ( } 7 \text { papers; } \\
12 \% \text { of strategic purchasing } \\
\text { papers) }\end{array}$ & $\begin{array}{l}\text { Development and testing of a } \\
\text { maturity model ( } 17 \text { papers; } \\
49 \% \text { of maturity papers) }\end{array}$ \\
\hline Comparative analysis & & $\begin{array}{l}\text { Review of the extent to which } \\
\text { strategic purchasing is } \\
\text { applied (incl. comparison } \\
\text { over time, across companies, } \\
\text { across countries etc.) ( } 5 \\
\text { papers; } 8 \% \text { of strategic } \\
\text { purchasing papers) }\end{array}$ & $\begin{array}{l}\text { Review of the extent to which } \\
\text { maturity is applied (incl. } \\
\text { comparison over time, across } \\
\text { companies, across countries } \\
\text { etc.) ( } 4 \text { papers; } 11 \% \text { of } \\
\text { maturity papers) }\end{array}$ \\
\hline $\begin{array}{l}\text { Relationships between } \\
\text { concepts }\end{array}$ & $\begin{array}{l}\text { Relationship between } \\
\text { alignment (Likert scale) and } \\
\text { other purchasing practices } \\
\text { and capabilities ( } 1 \text { papers; } 6 \% \\
\text { of strategic alignment papers) }\end{array}$ & $\begin{array}{l}\text { Relationship between } \\
\text { strategic purchasing and other } \\
\text { purchasing practices and } \\
\text { capabilities (14 papers; } 24 \% \text { ) }\end{array}$ & \\
\hline $\begin{array}{l}\text { Relationships with } \\
\text { performance }\end{array}$ & $\begin{array}{l}\text { Link alignment to } \\
\text { performance (5 papers; 28\%) }\end{array}$ & $\begin{array}{l}\text { Relationship between } \\
\text { strategic purchasing and } \\
\text { performance ( } 33 \text { papers; } 56 \% \\
\text { of strategic purchasing } \\
\text { papers) }\end{array}$ & $\begin{array}{l}\text { Relationship between } \\
\text { maturity and performance (14 } \\
\text { papers; } 40 \% \text { of maturity } \\
\text { papers) }\end{array}$ \\
\hline Total & 18 papers & 59 papers & 35 papers \\
\hline
\end{tabular}




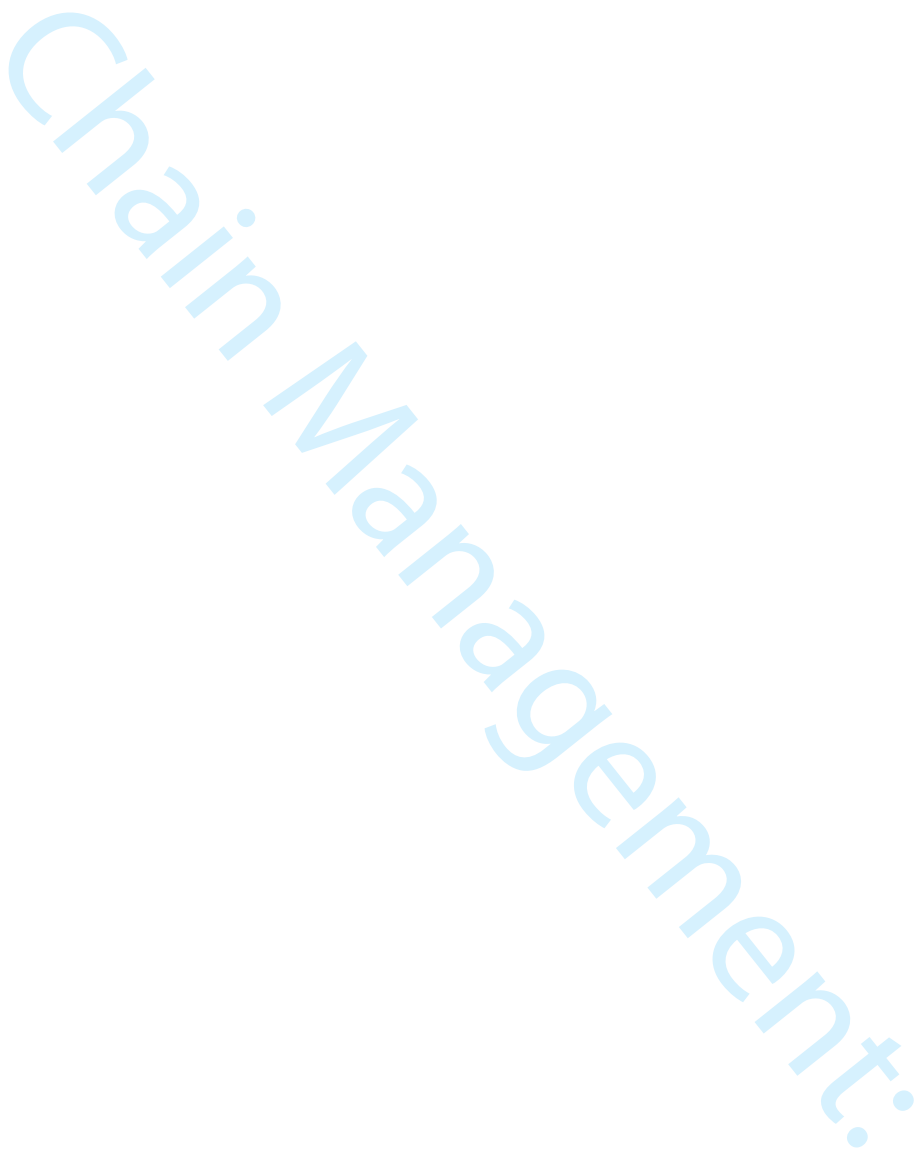


Table 6: Detailed comparison of theory, method, strengths and weaknesses by finding type

\begin{tabular}{|c|c|c|c|c|c|c|c|c|c|c|c|c|c|}
\hline \multirow[b]{2}{*}{ Theme } & \multirow[b]{2}{*}{ Finding type } & \multirow[b]{2}{*}{$\begin{array}{c}\text { Finding } \\
\text { summary }\end{array}$} & \multirow[b]{2}{*}{$\begin{array}{c}\text { Total } \\
\text { papers }\end{array}$} & \multicolumn{4}{|c|}{ Theory } & \multicolumn{3}{|c|}{ Method } & \multirow[b]{2}{*}{ Strengths } & \multirow[b]{2}{*}{ Weaknesses } & \multirow[b]{2}{*}{ References (by theory and method) } \\
\hline & & & & 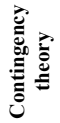 & $\overrightarrow{\underline{*}}$ & 宔 & 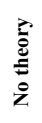 & 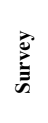 & 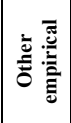 & 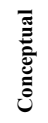 & & & \\
\hline \multirow{4}{*}{ 离 } & $\begin{array}{l}\text { Development } \\
\text { of } \\
\text { framework } \\
\text { and concepts }\end{array}$ & $\begin{array}{l}\text { Develop a } \\
\text { framework for } \\
\text { purchasing } \\
\text { strategic } \\
\text { alignment }\end{array}$ & 12 & 1 & 0 & 4 & 7 & 3 & 2 & 7 & $\begin{array}{l}\text { Papers build on } \\
\text { each other; } \\
\text { coherence on } \\
\text { concepts and } \\
\text { frameworks; } \\
\text { good theoretical } \\
\text { basis for most } \\
\text { papers }\end{array}$ & $\begin{array}{l}\text { Little empirical work to } \\
\text { test frameworks; Often } \\
\text { self-reported measures } \\
\text { of alignment (Likert } \\
\text { scale); Self-fulfilling } \\
\text { (frameworks usually } \\
\text { refer to 'right' practices, } \\
\text { but little definition of } \\
\text { what 'right' means - } \\
\text { except for Narasimhan } \\
\text { and Carter, 1998) }\end{array}$ & $\begin{array}{l}\text { Contingency theory - Other empirical: Pohl and } \\
\text { Förstl (2011) } \\
\text { Other theory - Survey: Mikalef et al. (2015); } \\
\text { Rozemeijer } \text { et al. (2003) } \\
\text { Other theory - Conceptual: Adamson (1980); Day } \\
\text { and Lichtenstein (2006) } \\
\text { No theory - Survey: Narasimhan and Carter (1998) } \\
\text { No theory - Other empirical: Caddick and Dale } \\
\text { (2007) } \\
\text { No theory - Conceptual: Farmer (1981); Watts et al. } \\
\text { (1992); Spekman (1989); Rajagopal and Bernard } \\
\text { (1993); Hesping and Schiele (2014) }\end{array}$ \\
\hline & $\begin{array}{l}\text { Comparative } \\
\text { analysis }\end{array}$ & $\mathrm{n} / \mathrm{a}$ & o & 0 & 0 & 0 & 0 & 0 & 0 & 0 & $\mathrm{n} / \mathrm{a}$ & $\mathrm{n} / \mathrm{a}$ & \\
\hline & $\begin{array}{l}\text { Link } \\
\text { between } \\
\text { themes }\end{array}$ & $\begin{array}{l}\text { Link alignment to } \\
\text { other purchasing } \\
\text { practices and } \\
\text { capabilities }\end{array}$ & 1 & 0 & 0 & 1 & 0 & 1 & 0 & 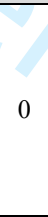 & $\begin{array}{l}\text { Good theoretical } \\
\text { basis; clear } \\
\text { framework } \\
\text { development; } \\
\text { robust } \\
\text { methodology \& } \\
\text { data analysis }\end{array}$ & $\begin{array}{l}\text { Self-assessed; similar } \\
\text { measurements (strategic } \\
\text { alignment is related to } \\
\text { internal integration); no } \\
\text { definition of how } \\
\text { strategic alignment can } \\
\text { be achieved }\end{array}$ & $\begin{array}{l}\text { Other theory - Survey: Kaufmann and Gaeckler } \\
(2015)\end{array}$ \\
\hline & $\begin{array}{l}\text { Link to } \\
\text { performance }\end{array}$ & $\begin{array}{l}\text { Link alignment to } \\
\text { performance }\end{array}$ & 5 & 2 & 2 & 1 & 0 & 4 & 1 & 0 & $\begin{array}{l}\text { Good theoretical } \\
\text { basis; clear } \\
\text { framework } \\
\text { development; } \\
\text { robust } \\
\text { methodology \& } \\
\text { data analysis }\end{array}$ & $\begin{array}{l}\text { Self-reported measure of } \\
\text { alignment (Likert scale) } \\
\text { is in contrast with some } \\
\text { of the conceptual papers } \\
\text { (little research on what } \\
\text { exactly 'right' practices } \\
\text { are) }\end{array}$ & $\begin{array}{l}\text { Contingency theory - Survey: Baier et al. (2008) } \\
\text { Contingency theory - Other empirical: David et al. } \\
\text { (2002) } \\
\text { RBV - Survey: Handfield et al. (2015); Kroes and } \\
\text { Ghosh (2010) } \\
\text { Other theory - Survey: Gonzáles-Benito (2007) }\end{array}$ \\
\hline 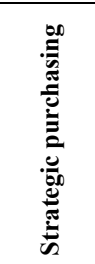 & $\begin{array}{l}\text { Development } \\
\text { of } \\
\text { framework } \\
\text { and concepts }\end{array}$ & $\begin{array}{l}\text { Review strategic } \\
\text { purchasing } \\
\text { concept }\end{array}$ & 7 & 0 & 0 & 1 & 6 & 4 & 1 & 2 & $\begin{array}{l}\text { Good knowledge } \\
\text { of purchasing } \\
\text { literature and } \\
\text { history; attempt } \\
\text { to unpack } \\
\text { purchasing's } \\
\text { development } \\
\text { over the decades }\end{array}$ & $\begin{array}{l}\text { Little exploratory work } \\
\text { (mostly conceptual or } \\
\text { testing of hypotheses); } \\
\text { consensus on framework } \\
\text { being challenged } \\
\text { (Ramsay and Croom, } \\
\text { 2008) }\end{array}$ & $\begin{array}{l}\text { Other theory - Survey: Ntayi and Mugume (2013) } \\
\text { No theory - Survey: Ramsay and Crrom (2008); Carr } \\
\text { and Smeltzer (1997); Kocabasoglu and Suresh (2006) } \\
\text { No theory - Other empirical: White et al. (2016) } \\
\text { No theory - Conceptual: Ellram and Carr (1994); } \\
\text { Matthews (2005) }\end{array}$ \\
\hline
\end{tabular}




\begin{tabular}{|c|c|c|c|c|c|c|c|c|c|c|c|c|c|}
\hline \multirow[b]{2}{*}{ Theme } & \multirow{2}{*}{ Finding type } & \multirow[b]{2}{*}{$\begin{array}{c}\text { Finding } \\
\text { summary }\end{array}$} & \multirow[b]{2}{*}{$\begin{array}{c}\text { Total } \\
\text { papers }\end{array}$} & \multicolumn{4}{|c|}{ Theory } & \multicolumn{3}{|c|}{ Method } & \multirow[b]{2}{*}{ Strengths } & \multirow[b]{2}{*}{ Weaknesses } & \multirow[b]{2}{*}{ References (by theory and method) } \\
\hline & & & & 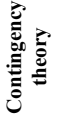 & 會 & 就 & : & $\stackrel{\vec{D}}{\bar{\Delta}}$ & 哀 & 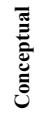 & & & \\
\hline & $\begin{array}{l}\text { Comparative } \\
\text { analysis }\end{array}$ & $\begin{array}{l}\text { Review the extent } \\
\text { to which strategic } \\
\text { purchasing is } \\
\text { applied (incl. } \\
\text { comparison over } \\
\text { time, across } \\
\text { companies, across } \\
\text { countries etc.) }\end{array}$ & & 0 & 0 & 1 & 4 & 4 & 1 & 0 & $\begin{array}{l}\text { Demonstrate } \\
\text { good knowledge } \\
\text { of purchasing } \\
\text { literature and } \\
\text { history }\end{array}$ & $\begin{array}{l}\text { Limited theoretical } \\
\text { basing; assume that } \\
\text { strategic purchasing is } \\
\text { generically desirable; } \\
\text { limited critical review of } \\
\text { concept }\end{array}$ & $\begin{array}{l}\text { Other theory - Other empirical: Christodoulidou et } \\
\text { al. (2012) } \\
\text { No theory - Survey: Quayle and Quayle (2000); } \\
\text { Quayle (1998); Pressey et al. (2009); Odgen } \text { et al. } \\
\text { (2007) }\end{array}$ \\
\hline & $\begin{array}{l}\text { Link } \\
\text { between } \\
\text { themes }\end{array}$ & $\begin{array}{l}\text { Link strategic } \\
\text { purchasing to } \\
\text { other purchasing } \\
\text { practices and } \\
\text { capabilities }\end{array}$ & 14 & 0 & $y$ & 2 & 12 & 8 & 3 & 3 & $\begin{array}{l}\text { Usually strong } \\
\text { methodology } \\
\text { and data analysis }\end{array}$ & $\begin{array}{l}\text { Limited theoretical } \\
\text { basing; assume that } \\
\text { strategic purchasing is } \\
\text { generically desirable; } \\
\text { limited critical review of } \\
\text { concept; empirical work } \\
\text { is usually based on self- } \\
\text { reported measures }\end{array}$ & $\begin{array}{l}\text { RBV - Survey: Sánchez-Rodriguez (2009); Carr and } \\
\text { Smeltzer (2000); Chen et al. (2004); Luzzini and } \\
\text { Ronchi (2016); Paulraj (2011); Revilla and Knoppen } \\
\text { (2014); Su (2012); Camarero Izquierdo et al. (2015); } \\
\text { Su et al. (2012) } \\
\text { RBV - Other empirical: Castaldi et al. (2011) } \\
\text { Other theory - Survey: Carr et al. (2000); Yeung et } \\
\text { al. (2015); Carr and Pearson (1999); Carr and } \\
\text { Smeltzer (1999); Bernardes and Zsidisin (2008) } \\
\text { No theory - Survey: Bowen } \text { et al. (2000); Pressey et } \\
\text { al. (2007); Paik et al. (2009); Lee and Humphreys } \\
\text { (2007); Spekman and Hill (1980); Zsidisin and Ellram } \\
\text { (2001); Carr and Pearson (2002); Narasimhan and Das } \\
\text { (2001); Knoppen and Sáenz (2015); Kim et al. (2012); } \\
\text { Yeung (2007); Carr and Smeltzer (1999) } \\
\text { No theory - Other empirical: Bemelmans et al. } \\
\text { (2013); Luzzini } \text { et al. (2014); Huang and Handfield } \\
\text { (2015) } \\
\text { No theory - Conceptual: Pearson and Gritzmacher } \\
\text { (1990); Trim (2005); Cousins et al. (2004) }\end{array}$ \\
\hline & $\begin{array}{l}\text { Link to } \\
\text { performance }\end{array}$ & $\begin{array}{l}\text { More strategic } \\
\text { purchasing = } \\
\text { better } \\
\text { performance }\end{array}$ & 33 & 0 & 14 & 5 & 14 & 31 & 2 & 0 & $\begin{array}{l}\text { Strong } \\
\text { theoretical basis; } \\
\text { strong build on } \\
\text { exisitng } \\
\text { literature (esp. } \\
\text { Carr and } \\
\text { Schmeltzer's } \\
\text { seminal paper) }\end{array}$ & $\begin{array}{l}\text { Usually self-reported } \\
\text { performance measures; } \\
\text { differences in } \\
\text { measurement and } \\
\text { conceptualisation of } \\
\text { strategic purchasing }\end{array}$ & $\begin{array}{l}\text { RBV - Survey: Lawson et al. (2007); Chiang et al. } \\
\text { (2010); Eltantawy and Giunipero (2013); Eltantawy et } \\
\text { al. (2014); Sánchez-Rodriguez (2009); Carr and } \\
\text { Smeltzer (2000); Chen et al. (2004); Luzzini and } \\
\text { Ronchi (2016); Paulraj (2011); Revilla and Knoppen } \\
\text { (2014); Su (2012); Camarero Izquierdo et al. (2015); } \\
\text { Su et al. (2012) } \\
\text { RBV - Other empirical: Castaldi et al. (2011) } \\
\text { Other theory - Survey: Paulraj and Chen (2007); } \\
\text { Kim and Chai (2017); Carr and Pearson (1999); Carr } \\
\text { and Smeltzer (1999); Bernardes and Zsidisin (2008) } \\
\text { No theory - Survey: Brookshaw and Terziovski } \\
\text { (2016); Paulraj (2005); Chan and Chin (2007); Chan et } \\
\text { al. (2007); Khan K and Pillania (2008); Cousins et al. }\end{array}$ \\
\hline
\end{tabular}




\begin{tabular}{|c|c|c|c|c|c|c|c|c|c|c|c|c|c|}
\hline \multirow{3}{*}{ Theme } & \multirow[b]{2}{*}{ Finding type } & \multirow[b]{2}{*}{$\begin{array}{c}\text { Finding } \\
\text { summary }\end{array}$} & \multirow[b]{2}{*}{$\begin{array}{c}\text { Total } \\
\text { papers }\end{array}$} & \multicolumn{4}{|c|}{ Theory } & \multicolumn{3}{|c|}{ Method } & \multirow[b]{2}{*}{ Strengths } & \multirow[b]{2}{*}{ Weaknesses } & \multirow[b]{2}{*}{ References (by theory and method) } \\
\hline & & & & 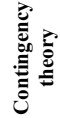 & 兴 & 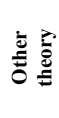 & 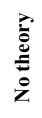 & 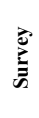 & 跑 & 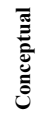 & & & \\
\hline & & & & & & & & & & & & & $\begin{array}{l}\text { (2006); Paulraj et al. (2006); Carr and Pearson (2002); } \\
\text { Narasimhan and Das (2001); Knoppen and Sáenz } \\
\text { (2015); Kim et al. (2012); Yeung (2007); Carr and } \\
\text { Smeltzer (1999) } \\
\text { No theory - Other empirical: Rossetti and Choi } \\
\text { (2005) }\end{array}$ \\
\hline \multirow{3}{*}{ 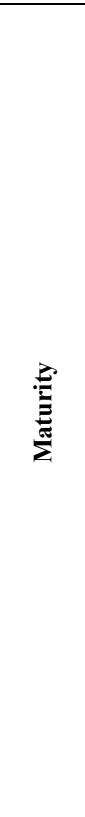 } & $\begin{array}{l}\text { Development } \\
\text { of } \\
\text { framework } \\
\text { and concepts }\end{array}$ & $\begin{array}{l}\text { Development of a } \\
\text { maturity model }\end{array}$ & 17 & 0 & 1 & 1 & 15 & 1 & 15 & 1 & $\begin{array}{l}\text { High level of } \\
\text { empirical } \\
\text { analysis }\end{array}$ & $\begin{array}{l}\text { Little theoretical basing } \\
\text { for development of } \\
\text { maturity models; no } \\
\text { critical review of 'fit' of } \\
\text { model with practitioner } \\
\text { expectations / processes; } \\
\text { assume that higher } \\
\text { maturity is better; } \\
\text { frameworks differ in } \\
\text { content and structure } \\
\text { (little alignment in } \\
\text { literature) }\end{array}$ & $\begin{array}{l}\text { Other theory - Survey: Mikalef et al. (2015) } \\
\text { RBV - Other empirical } \\
\text { Hartmann } \text { et al. (2014) } \\
\text { No theory - Other empirical: Reck and Long (1988); } \\
\text { Rendon (2008); Monczka and Trent (1991); Loppacher } \\
\text { et al. (2006); Barry et al. (1996); Freeman and } \\
\text { Cavinato (1990); Bemelmans et al. (2012); Prida and } \\
\text { Gutiérrez (1996); Tassabehji and Moorhouse (2008); } \\
\text { Beukers et al. (2006); Cavinato (1999); Deasy et al. } \\
\text { (2014) } \\
\text { No theory - Conceptual: Pearson and Gritzmacher } \\
\text { (1990) }\end{array}$ \\
\hline & $\begin{array}{l}\text { Comparative } \\
\text { analysis }\end{array}$ & $\begin{array}{l}\text { Review the extent } \\
\text { to which maturity } \\
\text { is applied (incl. } \\
\text { comparison over } \\
\text { time, across } \\
\text { companies, across } \\
\text { countries etc.) }\end{array}$ & 4 & 0 & 0 & 0 & 4 & 2 & 1 & 1 & $\begin{array}{l}\text { High level of } \\
\text { empirical } \\
\text { analysis }\end{array}$ & $\begin{array}{l}\text { No theoretical basis; } \\
\text { often self-reported } \\
\text { maturity; no critical } \\
\text { review of 'fit' of model } \\
\text { with practitioner } \\
\text { expectations / processes; } \\
\text { assume that higher } \\
\text { maturity is better; } \\
\text { frameworks differ in } \\
\text { content and structure } \\
\text { (little alignment in } \\
\text { literature) }\end{array}$ & $\begin{array}{l}\text { No theory - Survey: Pongsuwan (2016); Yavas et al. } \\
\text { (2007) } \\
\text { No theory - Other empirical: Van Lith et al. (2015) } \\
\text { No theory - Conceptual: Rajagopal and Bernard } \\
\text { (1993) }\end{array}$ \\
\hline & $\begin{array}{l}\text { Link } \\
\text { between } \\
\text { themes }\end{array}$ & $\mathrm{n} / \mathrm{a}$ & $\mathbf{0}$ & 0 & 0 & 0 & 0 & 0 & 0 & 0 & & & \\
\hline
\end{tabular}




\begin{tabular}{|c|c|c|c|c|c|c|c|c|c|c|c|c|c|}
\hline \multirow[b]{2}{*}{ Theme } & \multirow[b]{2}{*}{ Finding type } & \multirow[b]{2}{*}{$\begin{array}{c}\text { Finding } \\
\text { summary }\end{array}$} & \multirow[b]{2}{*}{$\begin{array}{c}\text { Total } \\
\text { papers }\end{array}$} & \multicolumn{4}{|c|}{ Theory } & \multicolumn{3}{|c|}{ Method } & \multirow[b]{2}{*}{ Strengths } & \multirow[b]{2}{*}{ Weaknesses } & \multirow[b]{2}{*}{ References (by theory and method) } \\
\hline & & & & 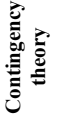 & $\overrightarrow{\underline{\underline{\Theta}}}$ & 总总 & 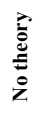 & 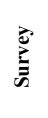 & 离 & 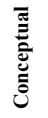 & & & \\
\hline & $\begin{array}{l}\text { Link to } \\
\text { performance }\end{array}$ & $\begin{array}{l}\text { Higher maturity = } \\
\text { better } \\
\text { performance }\end{array}$ & 14 & 0 & 0 & 2 & 12 & 12 & 2 & 0 & $\begin{array}{l}\text { High level of } \\
\text { empirical } \\
\text { analysis }\end{array}$ & $\begin{array}{l}\text { Little theoretical basing } \\
\text { for links between } \\
\text { maturity and } \\
\text { performance (generally } \\
\text { based on strategic } \\
\text { purchasing literature or } \\
\text { other maturity findings); } \\
\text { no critical review of 'fit' } \\
\text { of model with } \\
\text { practitioner expectations } \\
\text { / processes; assume that } \\
\text { higher maturity is better; } \\
\text { frameworks differ in } \\
\text { content and structure } \\
\text { (little alignment in } \\
\text { literature); self-assessed } \\
\text { measures for maturity } \\
\text { and performance }\end{array}$ & $\begin{array}{l}\text { Other theory - Survey: Rozemeijer et al. (2003) } \\
\text { Other theory - Other empirical: Schiele (2007) } \\
\text { No theory - Survey: Hartmann et al. (2012); Bozarth } \\
\text { et al. (1998); Ellram et al. (2002); Foerstl et al. (2012); } \\
\text { Mikalef } \text { et al. (2014); Trent and Monczka (2002); } \\
\text { Adams et al. (2016); Úbeda } \text { et al. (2015); Khan K and } \\
\text { Pillania (2008); Cousins } \text { et al. (2006); Paulraj } \text { et al. } \\
\text { (2006) } \\
\text { No theory - Other empirical: Bemelmans et al. } \\
\text { (2013); Luzzini } \text { et al. (2014); Versendaal } \text { et al. (2013) }\end{array}$ \\
\hline \multicolumn{3}{|l|}{ Total } & 104 & 3 & 17 & 16 & 68 & 65 & 26 & 13 & & & \\
\hline
\end{tabular}


Figure 2: Academic papers by maturity measurement, unit of analysis and alignment measures (Note: Some papers use more than one unit of analysis and/or conceptualisation of purchasing alignment)

Academic papers by maturity measurement, unit of analysis and alignment measure
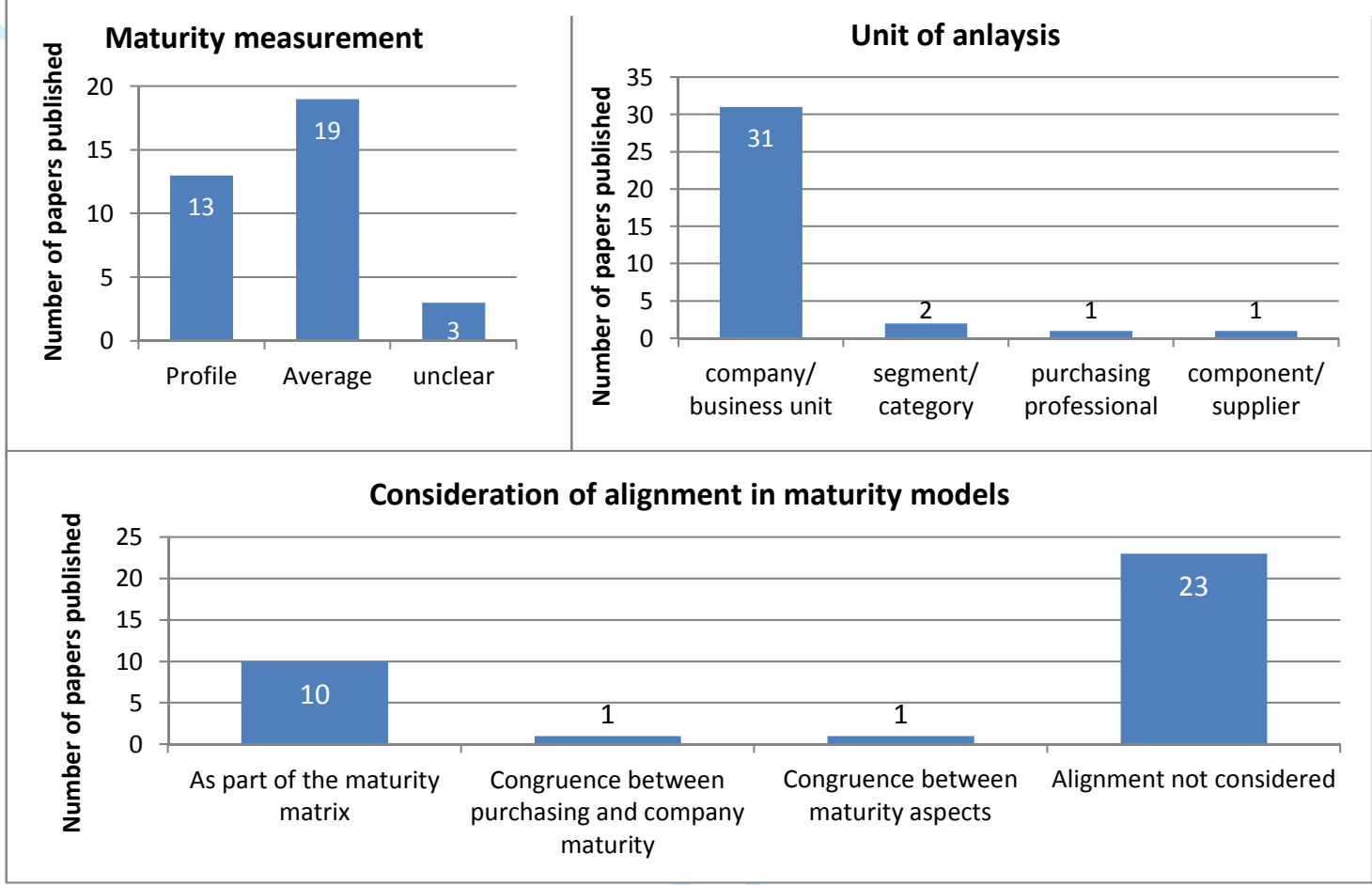
Table 7: Purchasing practice selection contingencies

\begin{tabular}{|c|c|c|}
\hline $\begin{array}{l}\text { Contingency group } \\
\text { (first order constructs) }\end{array}$ & $\begin{array}{c}\text { Contingencies } \\
\text { (second order constructs) }\end{array}$ & Description / example \\
\hline \multirow{3}{*}{$\begin{array}{l}\text { Internal or firm driven } \\
\text { contingencies }\end{array}$} & Company size & $\begin{array}{l}\text { About the selection of an IT system: "It would have to be implemented } \\
\text { globally, it would have to be scalable and it would have to be able to } \\
\text { handle the volumes that we are looking at" (BANK) }\end{array}$ \\
\hline & Company culture & $\begin{array}{l}\text { "You can't take one thing from one company and immediately transfer it } \\
\text { to another, because it has a different culture, it has a different way of } \\
\text { working..." (DRINK) }\end{array}$ \\
\hline & $\begin{array}{l}\text { Stakeholder and business } \\
\text { requirements }\end{array}$ & $\begin{array}{l}\text { "We went through our business requirements, what we wanted that to } \\
\text { deliver" (DRINK) }\end{array}$ \\
\hline \multirow{3}{*}{$\begin{array}{l}\text { External or demand } \\
\text { driven contingencies }\end{array}$} & $\begin{array}{l}\text { Industry specifics or } \\
\text { requirements }\end{array}$ & $\begin{array}{l}\text { e.g. regulations in the banking and finance industry (BANK) or the } \\
\text { competitive landscape (CAR) }\end{array}$ \\
\hline & $\begin{array}{l}\text { Benchmarks from } \\
\text { competitors }\end{array}$ & $\begin{array}{l}\text { "We did a couple of years ago do some benchmarking with CIPS and } \\
\text { other organisations that are out there" (DRINKS) }\end{array}$ \\
\hline & Consulting advice & $\begin{array}{l}\text { "we would research with some large organisations, like AT Kearney, like } \\
\text { some of the third parties, some of the consultants, and we'd evaluate } \\
\text { which strategy and which products and how we would implement them } \\
\text { would work best for us" (BANK) }\end{array}$ \\
\hline \multirow[b]{2}{*}{$\begin{array}{l}\text { Product or supply driven } \\
\text { contingencies }\end{array}$} & Product characteristics & $\begin{array}{l}\text { "As you better understand the dynamics of the products, and the cost } \\
\text { drivers, you find ways to be able to get value form that" (CAR) }\end{array}$ \\
\hline & Supplier market & $\begin{array}{l}\text { "I think the world's becoming a lot more risk aware. Now, when I say } \\
\text { risk I mean a number of things, whether that's financial risk, because of } \\
\text { the financial crisis, whether it's geopolitical risks" (BANK) }\end{array}$ \\
\hline
\end{tabular}


Table 8: Business strategy and purchasing aspect to be aligned

\begin{tabular}{|c|c|c|c|c|}
\hline Author & Research strategy & $\begin{array}{l}\text { Firm strategies } \\
\text { considered }\end{array}$ & $\begin{array}{l}\text { Purchasing aspect } \\
\text { to be aligned }\end{array}$ & Measurement basis for fit \\
\hline $\begin{array}{l}\text { Narasimhan } \\
\text { and Carter } \\
\text { (1998) }\end{array}$ & $\begin{array}{c}\text { Inductive: No } \\
\text { predefined } \\
\text { relationships between } \\
\text { firm strategies and } \\
\text { purchasing aspects }\end{array}$ & $\begin{array}{c}\text { Total quality, } \\
\text { differentiation/ } \\
\text { customisation, } \\
\text { traditional purchasing, } \\
\text { eco-organisation }\end{array}$ & $\begin{array}{l}\text { Purchasing } \\
\text { strategies }\end{array}$ & $\begin{array}{l}\text { Inductive: Empirically based } \\
\text { on correlation between factors }\end{array}$ \\
\hline $\begin{array}{l}\text { David et al. } \\
\text { (2002) }\end{array}$ & \multirow{4}{*}{$\begin{array}{l}\text { Deductive: } \\
\text { Predefined } \\
\text { relationships between } \\
\text { firm strategies and } \\
\text { purchasing aspects }\end{array}$} & $\begin{array}{c}\text { Cost leadership and } \\
\text { differentiation }\end{array}$ & $\begin{array}{c}\text { Level of } \\
\text { centralisation, scope } \\
\text { of activities }\end{array}$ & Deductive: Based on literature \\
\hline $\begin{array}{l}\text { Gonzáles- } \\
\text { Benito (2007) }\end{array}$ & & Not defined & $\begin{array}{c}\text { Quality, cost, } \\
\text { delivery, flexibility }\end{array}$ & $\begin{array}{c}\text { Inductive: Consistency } \\
\text { between weight assigned and } \\
\text { performance in different } \\
\text { aspects }\end{array}$ \\
\hline $\begin{array}{l}\text { Baier } \text { et al. } \\
\text { (2008) }\end{array}$ & & $\begin{array}{l}\text { Cost leadership and } \\
\text { differentiation }\end{array}$ & $\begin{array}{c}\text { Purchasing } \\
\text { priorities }\end{array}$ & $\begin{array}{l}\text { Inductive: Based on best- } \\
\text { performing firms }\end{array}$ \\
\hline $\begin{array}{l}\text { Kroes and } \\
\text { Ghosh (2010) }\end{array}$ & & $\begin{array}{c}\text { Cost, flexibility, } \\
\text { innovation, quality and } \\
\text { time }\end{array}$ & Outsourcing drivers & Deductive: Based on literature \\
\hline
\end{tabular}


Table 1: Purchasing and category strategy contingencies

\begin{tabular}{|c|c|c|}
\hline $\begin{array}{l}\text { Contingency group } \\
\text { (first order constructs) }\end{array}$ & $\begin{array}{c}\text { Contingencies } \\
\text { (second order constructs) }\end{array}$ & Description / example \\
\hline \multirow{4}{*}{$\begin{array}{l}\text { Internal or firm driven } \\
\text { contingencies }\end{array}$} & Firm strategy & $\begin{array}{l}\text { "the procurement strategy has to fit in with the overall company strategy" } \\
\text { (BANK) }\end{array}$ \\
\hline & Corporate principles & $\begin{array}{l}\text { "It's more around the corporate business principles that govern how we } \\
\text { go through the }[\ldots] \text { procurement process" (FOOD) }\end{array}$ \\
\hline & Firm culture & $\begin{array}{l}\text { "I think there's a certain culture } \ldots \text { just in terms of expectations of the } \\
\text { business" (CAR) }\end{array}$ \\
\hline & $\begin{array}{l}\text { Stakeholder and business } \\
\text { requirements }\end{array}$ & $\begin{array}{l}\text { "Ultimately, the business requirements I talked about are the absolute } \\
\text { bedrock of the whole process: Do we understand what we need?" } \\
\text { (DRINK) }\end{array}$ \\
\hline \multirow{3}{*}{$\begin{array}{l}\text { External or demand } \\
\text { driven contingencies }\end{array}$} & Geopolitical changes & $\begin{array}{l}\text { "And I'll give you a great example. We have a whole plan around } \\
\text { NAFTA, so around the trade agreement of North America; Canada, US, } \\
\text { Mexico. Guess what Donald Trump is going to do..." (BANK) }\end{array}$ \\
\hline & Customer or demand & $\begin{array}{l}\text { e.g. the requirement to work with original equipment manufacturers } \\
\text { (CAR) or the balance of high quality offering and the impact of } \\
\text { Christmas promotions on profitability (FOOD) }\end{array}$ \\
\hline & $\begin{array}{l}\text { Industry specifics or } \\
\text { requirements }\end{array}$ & $\begin{array}{l}\text { e.g. regulations in the banking and finance industry (BANK), the } \\
\text { requirement to reverse-engineer glass for new car models (CAR) or the } \\
\text { requirement to react to competitor behaviour (FOOD) }\end{array}$ \\
\hline \multirow{4}{*}{$\begin{array}{l}\text { Product or supply driven } \\
\text { contingencies }\end{array}$} & $\begin{array}{l}\text { Current contractual } \\
\text { arrangements }\end{array}$ & The contracts currently in place (DRINK) \\
\hline & Product complexity & Increasing product complexity through new technology (CAR) \\
\hline & Supplier market & $\begin{array}{l}\text { "the market has an impact, you know, how suppliers act, mergers and } \\
\text { acquisitions" (BANK) } \\
\text { "supplier market is about in the market they operate in: Is it expanding, is } \\
\text { it contracting? Where are those suppliers positioned strategically versus } \\
\text { each other? What are their focus areas?" (DRINK) } \\
\text { (this aspect was also mentioned by CAR and FOOD) }\end{array}$ \\
\hline & Future product development & How requirements may change in the future (DRINK) \\
\hline \multirow[b]{2}{*}{$\begin{array}{l}\text { Technological } \\
\text { contingencies }\end{array}$} & Systems vulnerability & $\begin{array}{l}\text { "We knew that we also had some reliance on critical areas, so things like } \\
\text { you don't want the ATMs to go down, you don't want people to be } \\
\text { hacking into your IT systems" (BANK) }\end{array}$ \\
\hline & Technology trends & $\begin{array}{l}\text { "the technology and where the technology is going is really important to } \\
\text { be able to develop good category strategies" (DRINK) } \\
\text { "we suddenly get a new technology, we develop something, and suddenly } \\
\text { we're selling five times as much as now - how can we cope with it? How } \\
\text { do we manage that, all those sort of things" (FOOD) }\end{array}$ \\
\hline
\end{tabular}

